\title{
PENDETAILAN TULANGAN STRUKTUR BETON BERTULANG TAHAN GEMPA SESUAI DENGAN SNI-03-2847-2002
}

\author{
Sugito Liono \\ Dosen Luar Biasa, Jurusan Teknik Sipil, Fakultas Teknik, \\ Universitas Kristen Maranatha, Bandung.
}

\begin{abstract}
ABSTRAK
Secara umum perencanaan struktur meliputi tiga proses utama yaitu proses analisis struktur, desain penampang dan pendetailan tulangan, analisis struktur menghasilkan gaya-gaya dalam, desain penampang menghasilkan penampang komponen struktur dengan jumlah baja tulangannya dan pendetailan menghasilkan detail-detail angkur, sambungan, lokasi sengkang-sengkang, jarak sengkang, tulangan ikat dll. Proses analisis dan desain yang baik akan menghasilkan sebuah penampang struktur yang proporsional dalam hal kekuatan, kemudahan pelaksanaan, biaya dll, tetapi untuk menghasilkan produk struktur yang baik harus diterapkan detail tulangan yang baik pula, tanpa pendetailan yang baik struktur tidak akan mampu menjaga kekuatannya terutama saat mengalami pergerakan akibat gempa. Beban gempa adalah beban yang bersifat bolak-balik, hanya dengan pendetailan tulangan yang baik maka struktur mampu berdeformasi diatas titik lelehnya sehingga mampu mengembangkan daktilitas yang dimilikinya dengan maksimal. SNI-03-28472002 sudah menyediakan ketentuan-ketentuan detail tulangan baik untuk struktur tahan gempa maupun untuk struktur biasa, untuk struktur tahan gempa SNI tersebut menyediakan dua tipe pendetailan yaitu untuk SRPMM dan SRPMK dimana keduanya dibedakan dari tingkat daktilitas yang dimiliki oleh struktur tersebut.
\end{abstract}

Kata kunci: detail tulangan, struktur tahan gempa, SRPMK, beton bertulang, SNI.

\begin{abstract}
Structural design involves three major process which are structural analysis, section design and reinforcement detailing, structural analysis produces internal forces, section design produces section with amount of reinforcements and reinforcement detailing produces anchorage detail, connection, location of stirrup, spacing of stirrup, tie etc. Good structural analysis and section design will produces proportional section in case of strength, workability, cost etc, but to produces good structure needs the application of good reinforcement detailing, these detailing will ensure the structural strength due to earthquake load. Earthquake load is a cyclic load, only with good reinforcement detailing the structure can deforms beyond its yield level and the structure can develop its ductility maximally. SNI-03-2847-2002 provides some reinforcement detailing requirements both for earthquake resistant structure and ordinary structure, two types of earthquake resistant structure detailing is provided for SRPMM and SRPMK which is different in its ductility level.
\end{abstract}

Keywords: detailing, earthquake resistant structure, SRPMK, reinforced concrete, SNI.

\section{PENDAHULUAN}

Dalam konstruksi beton bertulang ketentuan detail tulangan sering tidak diperhatikan dengan baik. Sebuah hasil perhitungan yang menunjukkan bahwa sebuah komponen struktur dinyatakan kuat tidak akan berarti jika tidak disertai dengan pendetailan tulangan yang memadai, banyak kerusakan-kerusakan struktur akibat gempa terjadi karena pendetailan tulangan yang buruk. Mengingat wilayah Indonesia terletak 
dalam wilayah kegempaan yang besar, ketentuan detail tulangan sangat memegang peranan penting dalam menjaga kekuatan struktur dalam menghadapi beban gempa. Dalam kenyataannya terlepas dari besar kecilnya struktur jika tidak diterapkan detail tulangan yang baik maka bisa terjadi resiko kegagalan pengangkuran dan kegagalan sambungan. Saat terjadi gempa sangat mungkin terjadi struktur tersebut tidak dapat menjaga kekuatan strukturnya sehingga mengalami kerusakan berat, karena tanpa aplikasi detail tulangan yang baik struktur tidak dapat mengembangkan daktilitasnya dengan maksimal.

\section{KRITERIA DESAIN STRUKTUR}

Sebuah struktur beton bertulang dapat direncanakan terhadap beban gravitasi saja atau kombinasi beban gravitasi dan beban gempa. Apapun kriteria desainnya struktur yang didesain gravitasi saja atau kombinasi gravitasi dan gempa kedua-duanya akan tetap terkena beban gempa sehingga ketentuan-ketentuan detail tulangan tahan gempa tetap harus diterapkan kepada struktur tersebut. Untuk struktur yang sangat sederhana seperti rumah tidak bertingkat penggunaan detail tulangan standar yang tidak tahan gempa mungkin masih bisa ditolerir, tetapi untuk struktur yang bertingkat minimal 2 tingkat walaupun desainnya hanya menerima beban gravitasi sebaiknya detail tulangan mengikuti detail tulangan tahan gempa, karena detail tulangan merupakan salah satu hal penting yang bisa diandalkan menjaga kekuatan strukturnya terutama saat struktur mengalami pergerakan akibat gempa.

Salah satu parameter penting yang sangat tidak pasti tetapi dapat merusak struktur adalah beban gempa. Sampai saat ini belum ada teknologi apapun yang bisa digunakan untuk memprediksi besaran dan karakterisktik gempa yang akan muncul, besaran dan karakterisktik gempa yang muncul bisa sangat beragam. Oleh karena itu peraturan-peraturan desain struktur juga selalu berubah, ketentuan-ketentuan detail tulangan selalu diperbaiki setiap tahunnya berdasarkan pengalaman-pengalaman gempa yang pernah terjadi agar diharapkan dapat mereduksi kerusakan-kerusakan struktur yang berat di kesempatan yang lain. Dari berbagai penelitian yang sudah dilakukan satu hal utama yang mampu sebagai penjaga kekuatan struktur adalah detail tulangan yang baik, detail tulangan tersebut dapat menjaga pengangkuran tulangan ke beton, menjaga sambungan-sambungan tulangan, menjaga sambungan pelat ke balok, balok ke kolom, kolom ke pondasi dll. Dengan detail tulangan yang baik sebuah struktur mampu mengembangkan daktilitasnya dengan lebih baik, diharapkan dengan pendetailan tulangan yang baik dapat mereduksi tingkat kerusakan struktur akibat beban gempa. 


\section{PENYALURAN DAN PENYAMBUNGAN TULANGAN}

\subsection{Umum}

Panjang penyaluran tulangan adalah panjang minimum yang dibutuhkan oleh baja tulangan yang tertanam di dalam beton dimana dengan panjang tertanam tersebut baja tulangan mampu mengembangkan tegangan lelehnya tanpa mengalami kegagalan. Semakin dalam baja tulangan tertanam dalam beton maka baja tulangan semakin mampu untuk mengembangkan kekuatannya.

Panjang penyambungan tulangan adalah panjang lewatan minimum yang dibutuhkan oleh 2 baja tulangan yang disambung tanpa sambungan mekanis. Jika 2 baja tulangan dengan diameter yang berbeda disambung maka nilai panjang penyambungan terbesar yang sebaiknya digunakan.

\subsection{Penyaluran Tulangan Ulir Lurus Kondisi Tarik}

Panjang penyaluran $l_{d}$ untuk batang tulangan ulir lurus kondisi tarik diambil minimum sebesar $300 \mathrm{~mm}$, untuk beberapa tipe diameter tulangan mengikuti persamaan umum berikut ini :

$$
\begin{array}{ll}
\mathrm{I}_{d}=\left(\frac{12 f_{y} \alpha \beta \lambda}{25 \sqrt{\mathrm{f}^{\prime} \mathrm{c}}}\right) d_{\mathrm{b}} & , \leq \mathrm{D} 19 \\
\mathrm{I}_{d}=\left(\frac{3 f_{y} \alpha \beta \lambda}{5 \sqrt{\mathrm{f}^{\prime} \mathrm{c}}}\right) d_{b} & , \geq \mathrm{D} 22
\end{array}
$$

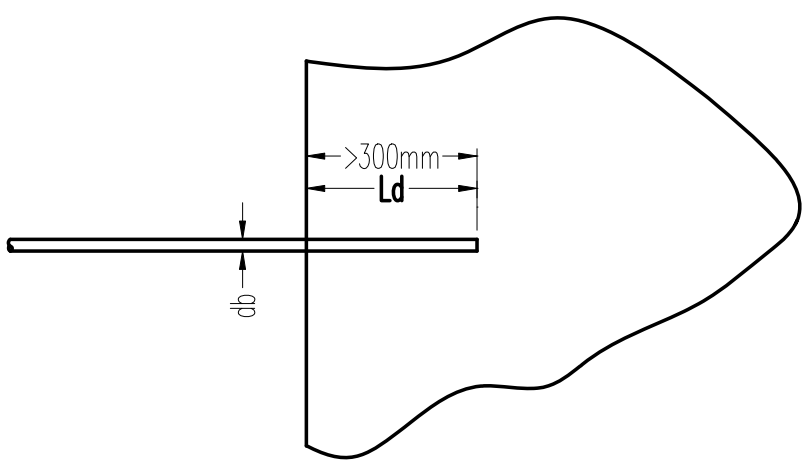

Gambar 1. Tulangan Ulir Lurus Kondisi Tarik.

Untuk kondisi normal, nilai $\alpha=1.0$ (tulangan lain), $\beta=1.0$ (tulangan tanpa pelapis), $\lambda=1.0$ (beton normal), untuk berbagai nilai $\mathrm{f}_{\mathrm{c}}{ }_{\mathrm{c}}$ dan nilai $\mathrm{f}_{\mathrm{y}}=400 \mathrm{MPa}$ nilai panjang penyaluran $\mathrm{l}_{\mathrm{d}}$ dapat diambil sesuai Tabel 1.

Pendetailan Tulangan Struktur Beton Bertulang Tahan Gempa Sesuai Dengan SNI-03-2847-2002 (Sugito Liono) 
Tabel 1.a Panjang Penyaluran Tulangan Ulir Lurus Kondisi Tarik $\leq$ D19.

\begin{tabular}{|c|c|c|c|c|c|c|c|}
\hline \multicolumn{7}{|c|}{ TULANGAN ULIR LURUS TARIK $\leq$ D19 } \\
\hline K (kg/cm $)$ & 225 & 250 & 300 & 350 & 400 & 450 & 500 \\
\hline $\mathrm{f}^{\prime}{ }_{\mathrm{c}}(\mathrm{MPa})$ & 18.68 & 20.75 & 24.90 & 29.05 & 33.20 & 37.35 & 41.50 \\
\hline $\mathrm{l}_{\mathrm{d}}$ & $45 \mathrm{~d}_{\mathrm{b}}$ & $43 \mathrm{~d}_{\mathrm{b}}$ & $39 \mathrm{~d}_{\mathrm{b}}$ & $36 \mathrm{~d}_{\mathrm{b}}$ & $34 \mathrm{~d}_{\mathrm{b}}$ & $32 \mathrm{~d}_{\mathrm{b}}$ & $30 \mathrm{~d}_{\mathrm{b}}$ \\
\hline
\end{tabular}

Tabel 1.b Panjang Penyaluran Tulangan Ulir Lurus Kondisi Tarik $\geq$ D22.

\begin{tabular}{|c|c|c|c|c|c|c|c|}
\hline \multicolumn{7}{|c|}{ TULANGAN ULIR LURUS TARIK $\geq$ D22 } \\
\hline K (kg/cm $)$ & 225 & 250 & 300 & 350 & 400 & 450 & 500 \\
\hline $\mathrm{f}^{\prime}{ }_{\mathrm{c}}(\mathrm{MPa})$ & 18.68 & 20.75 & 24.90 & 29.05 & 33.20 & 37.35 & 41.50 \\
\hline $\mathrm{l}_{\mathrm{d}}$ & $56 \mathrm{~d}_{\mathrm{b}}$ & $53 \mathrm{~d}_{\mathrm{b}}$ & $49 \mathrm{~d}_{\mathrm{b}}$ & $45 \mathrm{~d}_{\mathrm{b}}$ & $42 \mathrm{~d}_{\mathrm{b}}$ & $40 \mathrm{~d}_{\mathrm{b}}$ & $38 \mathrm{~d}_{\mathrm{b}}$ \\
\hline
\end{tabular}

Nilai $l_{d}$ diatas dapat direduksi dengan sebuah faktor $A_{s(\text { perlu) }} / A_{s(\text { pasang) }}$.

\subsection{Penyaluran Tulangan Ulir Lurus Kondisi Tekan}

Panjang penyaluran $l_{d}$ untuk batang tulangan ulir lurus kondisi tekan diambil minimum sebesar $200 \mathrm{~mm}$, untuk semua tipe diameter tulangan mengikuti persamaan umum berikut ini :

$$
I_{d}=\left(\frac{f_{y}}{4 \sqrt{f^{\prime} c}}\right) d_{b} \geq 0.04 d_{b} f_{y}
$$

Untuk berbagai nilai $\mathrm{f}_{\mathrm{c}}$ dan nilai $\mathrm{f}_{\mathrm{y}}=400 \mathrm{MPa}$ nilai panjang penyaluran $\mathrm{l}_{\mathrm{d}}$ dapat diambil sesuai tabel berikut.

Tabel 2. Panjang Penyaluran Tulangan Ulir Lurus Kondisi Tekan.

\begin{tabular}{|c|c|c|c|c|c|c|c|}
\hline \multicolumn{6}{|c|}{ TULANGAN ULIR LURUS TEKAN SEMUA DIAMETER } \\
\hline $\mathrm{K}\left(\mathrm{kg} / \mathrm{cm}^{2}\right)$ & 225 & 250 & 300 & 350 & 400 & 450 & 500 \\
\hline $\mathrm{f}^{\prime}{ }_{\mathrm{c}}(\mathrm{MPa})$ & 18.68 & 20.75 & 24.90 & 29.05 & 33.20 & 37.35 & 41.50 \\
\hline $\mathrm{l}_{\mathrm{d}}$ & $24 \mathrm{~d}_{\mathrm{b}}$ & $22 \mathrm{~d}_{\mathrm{b}}$ & $20 \mathrm{~d}_{\mathrm{b}}$ & $19 \mathrm{~d}_{\mathrm{b}}$ & $18 \mathrm{~d}_{\mathrm{b}}$ & $17 \mathrm{~d}_{\mathrm{b}}$ & $16 \mathrm{~d}_{\mathrm{b}}$ \\
\hline
\end{tabular}

Nilai $\mathrm{l}_{\mathrm{d}}$ diatas harus dikalikan dengan sebuah faktor $\mathrm{A}_{\mathrm{s}(\text { perlu) }} / \mathrm{A}_{\mathrm{s}(\text { pasang), }}$ atau dapat direduksi dengan faktor 0.75 jika tulangan tekan tersebut dililit oleh spiral $\phi 6-100$, atau dililit oleh sengkang D13-100. 


\subsection{Penyaluran Tulangan Ulir Kait $90^{\circ}$ dan $180^{\circ}$ Kondisi Tarik}

Panjang penyaluran $l_{\mathrm{dh}}$ untuk batang tulangan ulir berkait $90^{\circ}$ dan $180^{\circ}$ kondisi tarik (untuk $\mathrm{f}_{\mathrm{y}}=400 \mathrm{MPa}$ ) diambil minimum sebesar $150 \mathrm{~mm}$ atau $8 \mathrm{~d}_{\mathrm{b}}$, untuk semua tipe diameter tulangan mengikuti persamaan umum berikut ini :

$$
I_{d h}=\left(\frac{100}{\sqrt{f^{\prime}{ }_{c}}}\right) d_{b}
$$

Untuk berbagai nilai $\mathrm{f}_{\mathrm{c}}{ }_{\mathrm{c}}$ nilai panjang penyaluran $\mathrm{l}_{\mathrm{dh}}$ dapat diambil sesuai tabel berikut.

Tabel 3. Panjang Penyaluran Tulangan Berkait Kondisi Tarik.

\begin{tabular}{|c|c|c|c|c|c|c|c|}
\hline \multicolumn{7}{|c|}{ TULANGAN ULIR KAIT TARIK SEMUA DIAMETER } \\
\hline $\mathrm{K}\left(\mathrm{kg} / \mathrm{cm}^{2}\right)$ & 225 & 250 & 300 & 350 & 400 & 450 & 500 \\
\hline $\mathrm{f}^{\prime}{ }_{\mathrm{c}}(\mathrm{MPa})$ & 18.68 & 20.75 & 24.90 & 29.05 & 33.20 & 37.35 & 41.50 \\
\hline $\mathrm{l}_{\mathrm{dh}}$ & $24 \mathrm{~d}_{\mathrm{b}}$ & $22 \mathrm{~d}_{\mathrm{b}}$ & $20 \mathrm{~d}_{\mathrm{b}}$ & $19 \mathrm{~d}_{\mathrm{b}}$ & $18 \mathrm{~d}_{\mathrm{b}}$ & $17 \mathrm{~d}_{\mathrm{b}}$ & $16 \mathrm{~d}_{\mathrm{b}}$ \\
\hline
\end{tabular}

Nilai $l_{\mathrm{dh}}$ diatas harus dikalikan dengan faktor-faktor modifikasi yaitu:

- Untuk tulangan dengan $\mathrm{f}_{\mathrm{y}}$ selain $400 \mathrm{MPa}$, dikalikan dengan faktor $\left(\mathrm{f}_{\mathrm{y}} / 400\right)$.

- Untuk tulangan $\leq$ D36 dengan tebal selimut beton samping tidak kurang dari $60 \mathrm{~mm}$, dan untuk kait $90^{\circ}$ dengan tebal selimut beton tidak kurang dari $50 \mathrm{~mm}$, dikalikan dengan faktor 0.70 .

- Untuk tulangan $\leq$ D36 dengan kait yang secara vertikal atau horisontal berada dalam daerah yang dilingkupi sengkang/sengkang ikat yang dipasang sepanjang $l_{\text {dh }}$ dengan spasi tidak melebihi $3 \mathrm{~d}_{\mathrm{b}}$, dikalikan dengan faktor 0.80 .

- Dikalikan dengan faktor $\mathrm{A}_{\mathrm{s} \text { (perlu) }} / \mathrm{A}_{\mathrm{s} \text { (pasang). }}$.

- Untuk beton agregat ringan, dikalikan dengan faktor 1.30.

- Untuk tulangan berlapis epoksi, dikalikan dengan faktor 1.20.

- Untuk tulangan yang disalurkan dengan kait standar pada ujung yang tidak menerus dengan selimut beton kurang dari $60 \mathrm{~mm}$, tulangan berkait tersebut harus dilingkupi dengan sengkang/sengkang ikat di sepanjang $\mathrm{l}_{\mathrm{dh}}$ dengan spasi tidak lebih dari $3 \mathrm{~d}_{\mathrm{b}}$. 


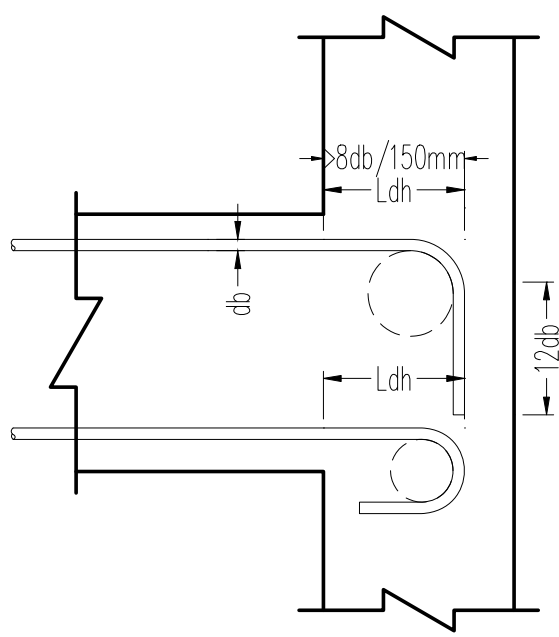

Gambar 2. Tulangan Ulir Berkait Kondisi Tarik.

\subsection{Sambungan Tulangan Ulir Kondisi Tarik}

Panjang minimum sambungan lewatan tulangan dalam kondisi tarik tidak boleh kurang dari $300 \mathrm{~mm}$. Terdapat 2 kelas sambungan lewatan yang dapat digunakan yaitu sambungan kelas A sebesar $1.0 l_{d}$ dan sambungan kelas B sebesar $1.30 l_{d}$. Sambungan kelas A hanya diperbolehkan untuk digunakan jika jumlah tulangan terpasang minimum dua kali lebih besar dari jumlah tulangan berdasarkan perhitungan dan maksimum hanya setengah dari tulangan yang disambung.

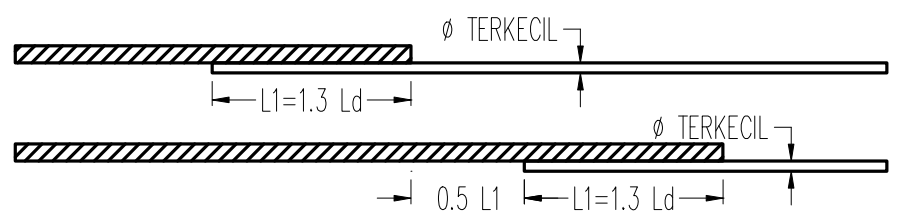

Gambar 3. Sambungan Tulangan Ulir Kondisi Tarik.

\subsection{Sambungan Tulangan Ulir Kondisi Tekan}

Panjang sambungan lewatan tulangan dalam kondisi tekan tidak boleh kurang dari $300 \mathrm{~mm}$, untuk setiap nilai $\mathrm{f}_{\mathrm{y}}$ harus diambil sesuai dengan persamaan :

$$
\begin{aligned}
& 0.07 f_{y} d_{b} \quad \text {,untuk } f_{y} \leq 400 \mathrm{MPa} \\
& \left(0.13 f_{y}-24\right) d_{b} \text {, untuk } f_{y}>400 \mathrm{MPa}
\end{aligned}
$$

Untuk nilai $\mathrm{f}_{\mathrm{y}}=240 \mathrm{MPa}$ dan $\mathrm{f}_{\mathrm{y}}=400 \mathrm{MPa}$, nilai sambungan lewatan tulangan dalam kondisi tekan dapat dilihat pada tebal berikut. Penggunaan kait tidak boleh dianggap efektif untuk tulangan kondisi tekan. 
Tabel 4. Sambungan Lewatan Tulangan Ulir Kondisi Tekan. SAMBUNGAN LEWATAN TULANGAN ULIR TEKAN

\begin{tabular}{|c|c|c|}
\hline $\mathrm{f}_{\mathrm{y}}(\mathrm{MPa})$ & 240 & 400 \\
\hline $\mathrm{L}$ & $17 \mathrm{~d}_{\mathrm{b}}$ & $28 \mathrm{~d}_{\mathrm{b}}$ \\
\hline
\end{tabular}

\subsection{Ketentuan Sambungan Lewatan Pada Kolom}

Untuk komponen struktur tekan dengan sengkang/sengkang ikat, panjang sambungan lewatan dapat dikalikan dengan faktor 0.83 tetapi tidak boleh kurang dari 300 mm, dengan syarat luas luas efektif sengkang/sengkang ikat tidak kurang dari $(0.0015 \cdot \mathrm{h} \cdot \mathrm{s})$. Untuk komponen struktur tekan dengan spiral, panjang sambungan lewatan dapat dikalikan dengan faktor 0.75 tetapi tidak boleh kurang dari $300 \mathrm{~mm}$.

\section{DETAIL TULANGAN}

\subsection{Kait Standar}

SNI-03-2847-2002 menetapkan beberapa tipe kait standar seperti kait $90^{\circ}, 180^{\circ}$, kait-kait sengkang dan tulangan ikat dengan sudut kait $135^{\circ}$ dll.
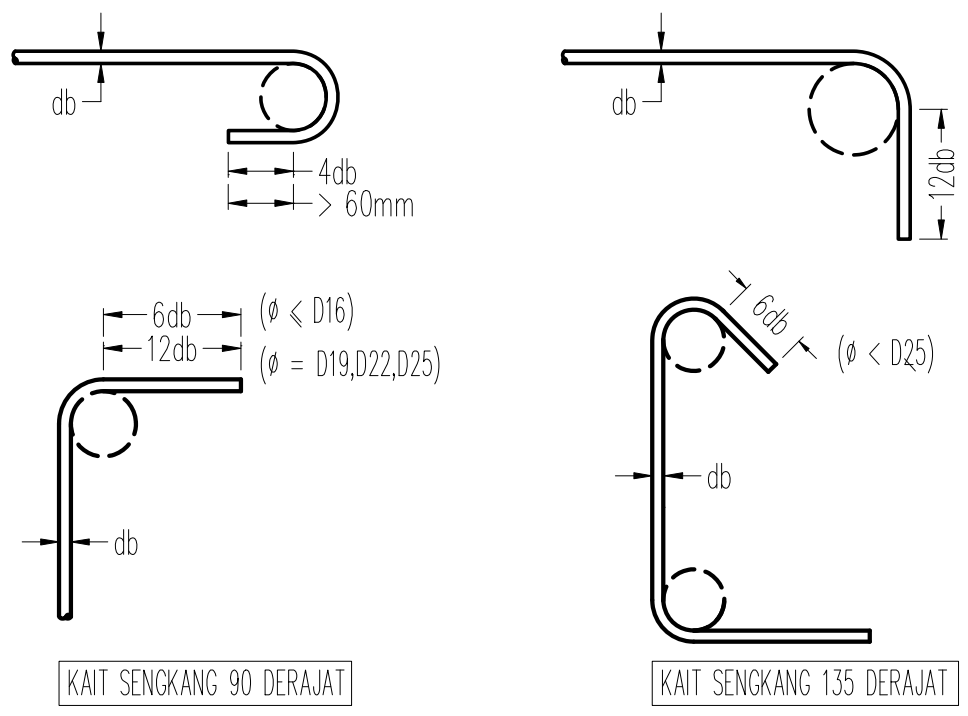

Gambar 4. Kait-Kait Standar.

\subsection{Tulangan Lateral Komponen Struktur Tekan}

Komponen struktur tekan adalah elemen struktur dimana gaya dalam yang paling dominan adalah gaya aksial tekan atau kombinasi gaya aksial tekan dengan momen lentur. Peranan tulangan lateral sangat penting dalam komponen struktur tekan karena 
akibat gaya aksial tekan tulangan longitudinal dapat beresiko mengalami tekuk yang akan mengakibatkan komponen struktur tersebut menggembung dan kehilangan kekuatannya.

Tulangan lateral berupa spiral harus merupakan batang tulangan yang menerus, diameter tulangan spiral tidak boleh kurang dari $10 \mathrm{~mm}$, khusus untuk tulangan spiral diijinkan untuk menggunakan tulangan polos, spasi maksimum dari tulangan spiral adalah $75 \mathrm{~mm}$ dengan spasi minimumnya sebesar $25 \mathrm{~mm}$.

Tulangan lateral berupa sengkang pengikat diatur dalam SNI-03-2847-2002 sebagai berikut :

- Sengkang/sengkat ikat lateral mempunyai diameter minimum sebesar $10 \mathrm{~mm}$ berupa tulangan ulir untuk tulangan longitudinal $\leq$ D32, sedangkan untuk tulangan D36, D44, D56 minimum harus digunakan diameter sengkang pengikat D13.

- Spasi vertikal sengkang/sengkang ikat tidak boleh melebihi $16 \mathrm{~d}_{b}, 48 \mathrm{~d}_{\mathrm{s}}$, atau dimensi terkecil dari komponen struktur tersebut.

- Penempatan sengkang/sengkang ikat harus sesuai dengan sketsa yang tergambar berikut.

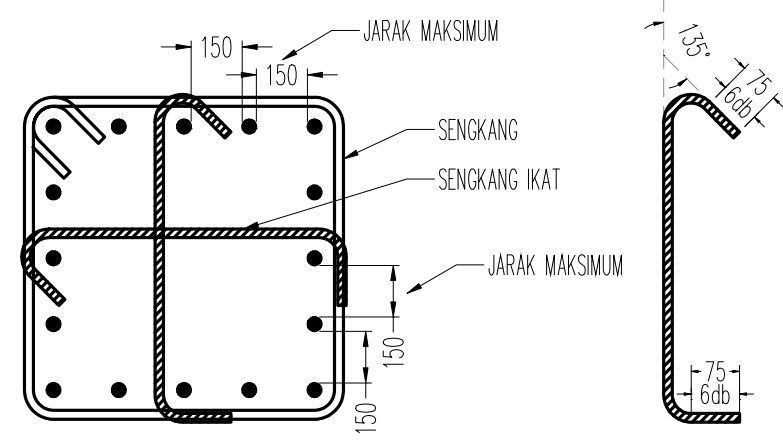

Gambar 5. Sengkang dan Sengkang Ikat.

\subsection{Tulangan Lateral Komponen Struktur Lentur}

Pada bagian komponen struktur lentur yang mengalami tegangan bolak-balik harus dilingkupi dengan sengkang/sengkang ikat tertutup yang dapat dibentuk dalam satu unit atau dibentuk dari dua unit yang disambung dengan sambungan lewatan $1.30 l_{\mathrm{d}}$.

\section{DETAIL TULANGAN TAHAN GEMPA}

\subsection{Umum}

Pasal 23 dalam SNI-03-2847-2002 mengatur tentang ketentuan detail tulangan untuk struktur tahan gempa. Ketentuan detail tulangan yang telah disebutkan diatas (pasal 9 dalam SNI-03-2847-2002) berlaku untuk struktur-struktur yang tidak direncanakan tahan gempa, untuk struktur tahan gempa semua ketentuan tersebut harus digantikan oleh 
kententuan yang tercantum dalam pasal 23. Sebagai contoh sebuah struktur yang direncanakan hanya terhadap beban gravitasi tetapi dikehendaki agar mampu tahan gempa berarti ketentuan detail tulangan mengikuti ketentuan di pasal 23. Dalam SNI-032847-2002 diatur beberapa ketentuan detail tulangan sesuai dengan sistem rangka yang digunakan. Untuk sistem rangka yang direncanakan berperilaku elastis dapat menggunakan ketentuan detail tulangan pasal 9, untuk sistem rangka yang direncanakan berperilaku daktail menengah (sistem rangka pemikul momen menengah/SRPMM) atau berperilaku daktail penuh (sistem rangka pemikul momen khusus/SRPMK) harus mengikuti ketentuan detail tulangan dalam pasal 23.

\subsection{Ketentuan Detail Tulangan SRPMM}

SRPMM adalah sistem rangka pemikul momen menengah dimana struktur rangka beton bertulang direncanakan berperilaku daktail menengah artinya tidak semua kapasitas daktilitas strukturnya dikerahkan semuanya. Desain tersebut dilakukan dengan membagi gaya gempa elastis dengan sebuah faktor yang sedang sehingga struktur direncanakan dengan nilai beban gempa yang lebih kecil tapi dengan pendetailan tulangan yang sesuai diharapkan saat terjadi gempa tidak terjadi kerusakan-kerusakan yang berat. Karena daktilitas yang dikerahkan masih dalam tingkat menengah maka detail tulangan yang disyaratkan juga tidak terlalu ketat, terutama dalam pendetailan elemen-elemen vertikalnya.

Untuk elemen lentur balok, SNI-03-2847-2002 menerapkan beberapa ketentuan penting detail tulangan SRPMM sebagai berikut :

- Jumlah tulangan positif di muka kolom tidak lebih kecil dari 1/3 jumlah tulangan negatif pada lokasi yang sama.

- Jumlah tulangan positif dan negatif pada sepanjang bentang tidak lebih kecil dari 1/5 jumlah tulangan terbesar pada kedua muka kolom.

- Di kedua ujung balok harus dipasang sengkang sepanjang lokasi 2h (h=tinggi balok) diukur dari muka kolom ke tengah bentang, spasi sengkang pertama $50 \mathrm{~mm}$. Spasi maksimum sengkang di lokasi tersebut tidak boleh lebih dari d/4, 8d $\mathrm{d}_{\mathrm{b}}, 24 \mathrm{~d}_{\mathrm{s}}, 300 \mathrm{~mm}$. Lokasi sepanjang $2 \mathrm{~h}$ adalah lokasi dimana diharapkan terjadi sendi plastis.

- Sengkang di sepanjang bentang balok tidak boleh dipasang dengan spasi melebihi d/2. 


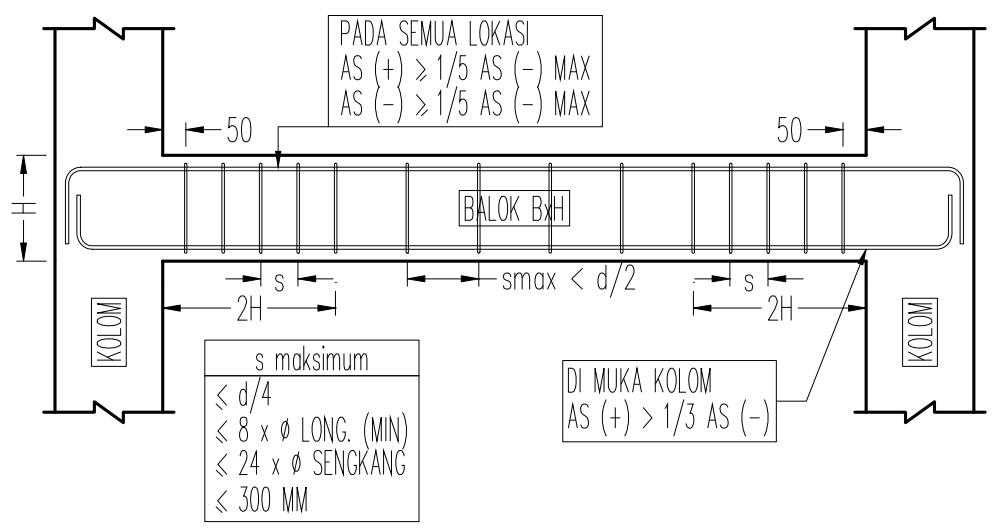

Gambar 6. Detail Balok SRPMM.

Untuk elemen aksial-lentur kolom, SNI-03-2847-2002 menerapkan beberapa ketentuan penting detail tulangan SRPMM sebagai berikut :

- Ditetapkan sebuah panjang $L_{0}$ yaitu lokasi dimana diharapkan terjadi sendi plastis, panjang $L_{o}$ diambil sebagai nilai terbesar dari $1 / 6 \mathrm{H}_{\mathrm{n}}, \mathrm{h}_{\text {kolom, }}, 500 \mathrm{~mm} . \mathrm{H}_{\mathrm{n}}$ adalah tinggi bersih kolom, h adalah dimensi penampang kolom terbesar.

- Pada daerah $L_{o}$ harus dipasang sengkang dengan spasi $s_{0}$ tidak melebihi $8 d_{b}, 24 d_{s}, 1 / 2$ b, 300 mm. Dimana "b" adalah dimensi penampang kolom terkecil.

- Pada lokasi selain $\mathrm{L}_{\mathrm{o}}$ spasi sengkang dipasang dengan jarak maksimum $2 \mathrm{~s}_{0}$. 


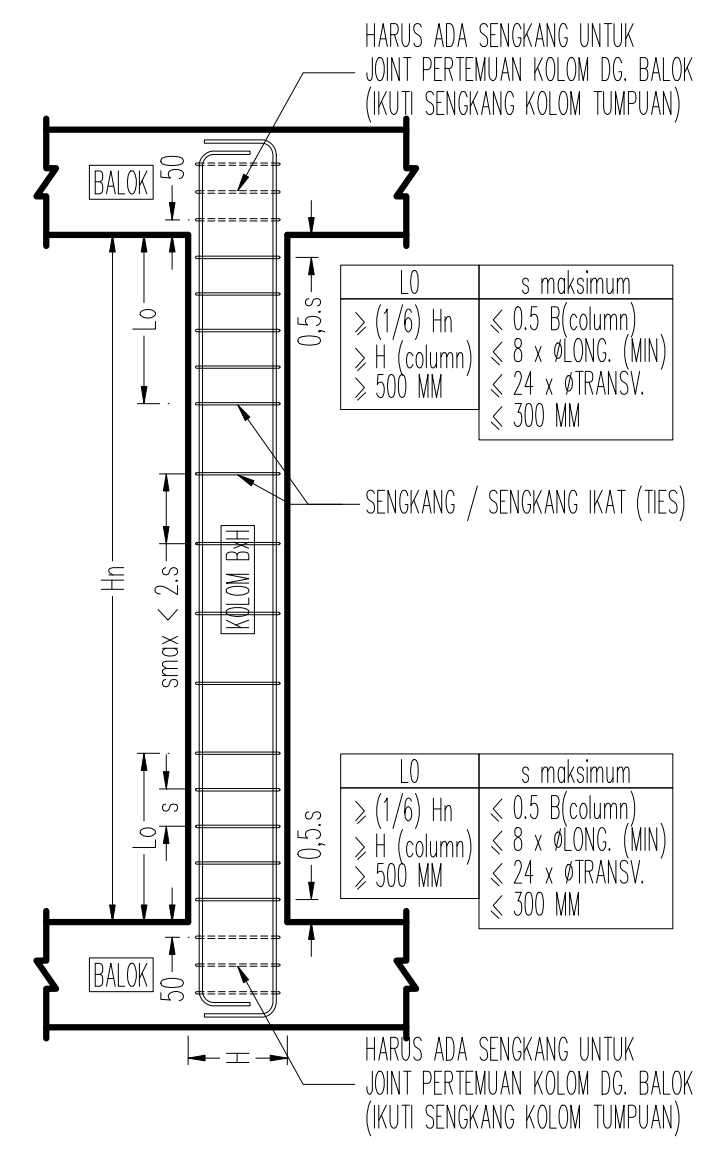

Gambar 7. Detail Kolom SRPMM.

\subsection{Ketentuan Detail Tulangan SRPMK}

SRPMK adalah sistem rangka pemikul momen khusus dimana struktur rangka beton bertulang direncanakan berperilaku daktail penuh artinya semua kapasitas daktilitas strukturnya dikerahkan secara maksimal. Desain tersebut dilakukan dengan membagi gaya gempa elastis dengan sebuah faktor yang besar sehingga struktur direncanakan dengan nilai beban gempa yang kecil sekali tapi dengan pendetailan tulangan yang sesuai diharapkan saat terjadi gempa tidak terjadi kerusakan-kerusakan yang berat karena strukturnya mampu mengembangkan daktilitasnya secara penuh. Karena daktilitas yang dikerahkan sudah maksimal maka detail tulangan yang disyaratkan juga cukup ketat, terutama dalam pendetailan elemen-elemen vertikalnya.

Untuk elemen lentur balok, SNI-03-2847-2002 menerapkan beberapa ketentuan penting detail tulangan SRPMK sebagai berikut :

- Jumlah tulangan positif di muka kolom tidak lebih kecil dari 1/2 jumlah tulangan negatif pada lokasi yang sama. 
- Jumlah tulangan positif dan negatif pada sepanjang bentang tidak lebih kecil dari 1/4 jumlah tulangan terbesar pada kedua muka kolom.

- Di kedua ujung balok harus dipasang sengkang sepanjang lokasi 2h ( $\mathrm{h}=$ =tinggi balok) diukur dari muka kolom ke tengah bentang, spasi sengkang pertama $50 \mathrm{~mm}$. Spasi maksimum sengkang di lokasi tersebut tidak boleh lebih dari d/4, 8d $\mathrm{d}_{\mathrm{b}}, 24 \mathrm{~d}_{\mathrm{s}}, 300 \mathrm{~mm}$. Lokasi sepanjang $2 \mathrm{~h}$ adalah lokasi dimana diharapkan terjadi sendi plastis.

- Sengkang di sepanjang bentang balok tidak boleh dipasang dengan spasi melebihi d/2.

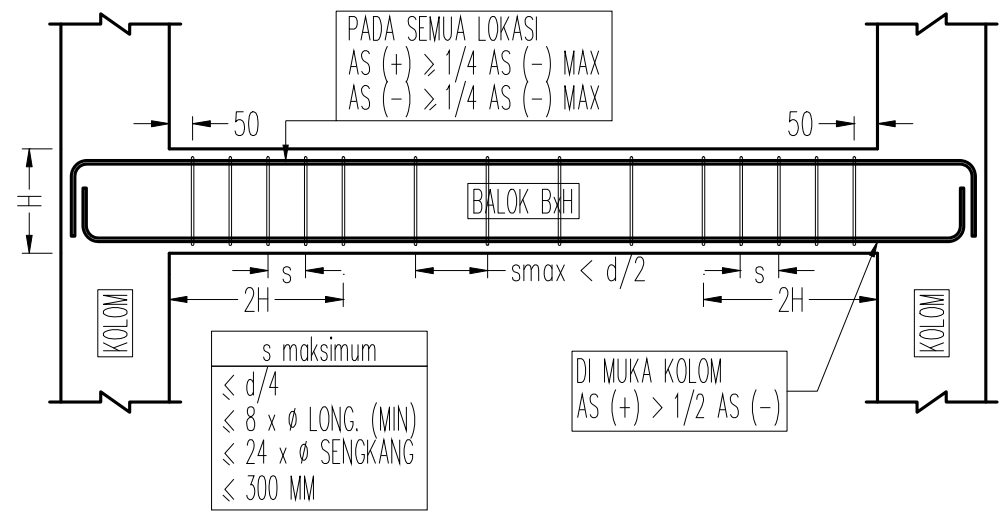

Gambar 8. Detail Balok SRPMK.

Untuk elemen aksial-lentur kolom, SNI-03-2847-2002 menerapkan beberapa ketentuan penting detail tulangan SRPMK sebagai berikut :

- Ditetapkan sebuah panjang $L_{o}$ yaitu lokasi dimana diharapkan terjadi sendi plastis, panjang $\mathrm{L}_{\mathrm{o}}$ diambil sebagai nilai terbesar dari $1 / 6 \mathrm{H}_{\mathrm{n}}$, h kolom, $500 \mathrm{~mm} . \mathrm{H}_{\mathrm{n}}$ adalah tinggi bersih kolom, h adalah dimensi penampang kolom terbesar. Pada daerah $\mathrm{L}_{\mathrm{o}}$ harus dipasang sengkang dengan spasi tidak melebihi $6 \mathrm{~d}_{\mathrm{b}}, 1 / 4 \mathrm{~b}$, $\mathrm{s}_{\mathrm{x}}=100+\left(\frac{350-\mathrm{h}_{\mathrm{x}}}{3}\right) \Rightarrow 100 \leq \mathrm{s}_{\mathrm{x}} \leq 150$. Dimana "b" adalah dimensi penampang kolom terkecil.

- Jika nilai gaya aksial pada kolom melebih $0.1 \mathrm{f}_{\mathrm{c}} \mathrm{A}_{\mathrm{g}}$, maka sengkang tersebut diatas dipasang di seluruh tinggi kolom. Jika tidak maka pada lokasi selain $\mathrm{L}_{0}$, spasi sengkang dipasang dengan jarak maksimum $6 \mathrm{~d}_{\mathrm{b}} / 150 \mathrm{~mm}$, diambil nilai yang terkecil.

- Pada ujung kolom yang berhenti di pondasi (pilecap, telapak) atau dinding beton bertulang maka sengkang tersebut diatas harus diteruskan sampai ke dalam pondasi sepanjang panjang penyaluran tarik. 


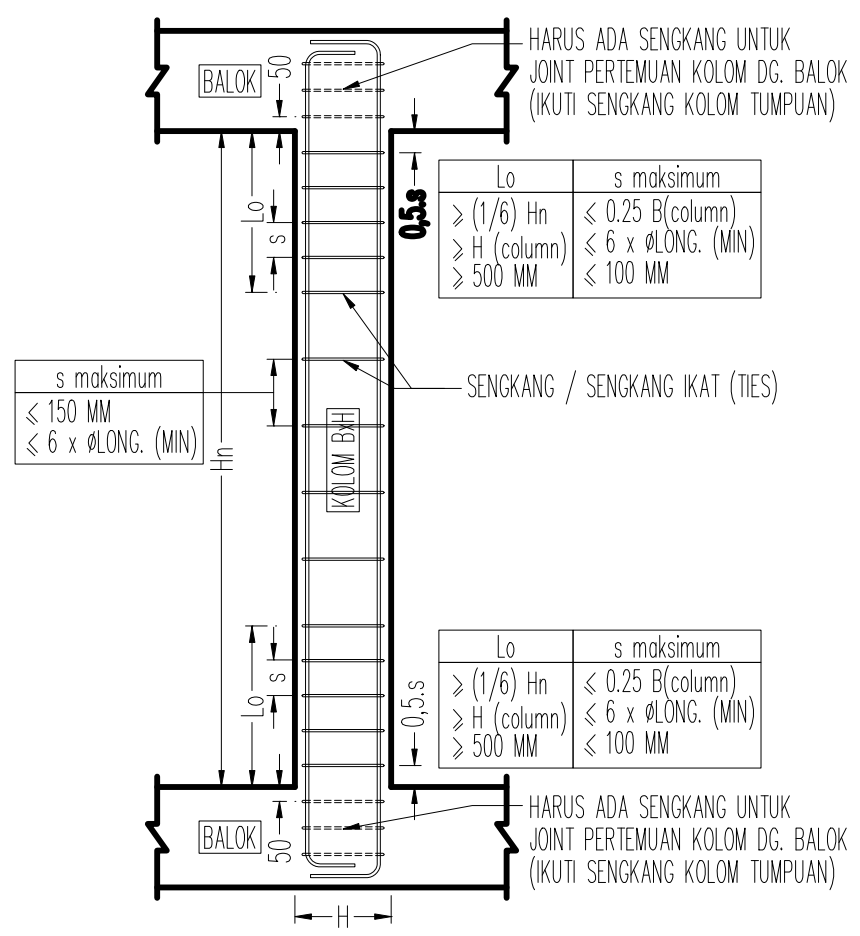

Gambar 9. Detail Kolom SRPMK.

Untuk joint balok-kolom, SNI-03-2847-2002 menerapkan beberapa ketentuan penting detail tulangan SRPMK sebagai berikut :

- Untuk beton berat normal, panjang penyaluran tulangan berkait $90^{\circ}$ dalam kondisi tarik diambil minimum sebesar $8 d_{b}$, $150 \mathrm{~mm}$ dan $I_{d h}=\left(\frac{f_{y}}{5.4 \sqrt{f_{c}^{\prime}}}\right) d_{b}$, ini berlaku untuk diameter D10 sampai dengan D36. Panjang $l_{d h}$ ini untuk $f_{y}=400$ MPa jika diperhatikan lebih lebih pendek daripada $l_{\text {dh }}$ untuk struktur tidak tahan gempa, hal tersebut karena persamaan tersebut sudah menggunakan faktor modifikasi 0.70 (faktor selimut beton) dan 0.80 (untuk joint terkekang sengkang).

- Panjang penyaluran lurus dalam kondisi tarik diambil sebesar $2.5 \times \mathrm{l}_{\mathrm{dh}}$ kait $90^{\circ}$ jika tebal beton di bawah tulangan kurang dari $300 \mathrm{~mm}$, dan $3.25 \times \mathrm{l}_{\mathrm{dh}}$ kait $90^{\circ}$ jika tebal beton di bawah tulangan lebih dari $300 \mathrm{~mm}$.

- Tulangan tanpa kait harus berhenti pada joint balok-kolom dan diteruskan melewati inti beton terkekang, semua bagian yang tidak melewati inti terkekang harus diperpanjang 1.6 kali.

- Untuk sengkang/sengkang ikat diatur seperti gambar sketsa di bawah ini. Luas total sengkang/sengkang ikat untuk tiap arah gaya geser tidak boleh kurang dari : 


$$
\begin{gathered}
\frac{A_{s h}}{s}=\left(\frac{b_{c} f^{\prime} c}{f_{y}}\right)\left(\frac{A_{g}}{A_{c h}}-1\right) \\
\frac{A_{s h}}{s}=0.09\left(\frac{b_{c} f^{\prime}{ }_{c}}{f_{y}}\right)
\end{gathered}
$$

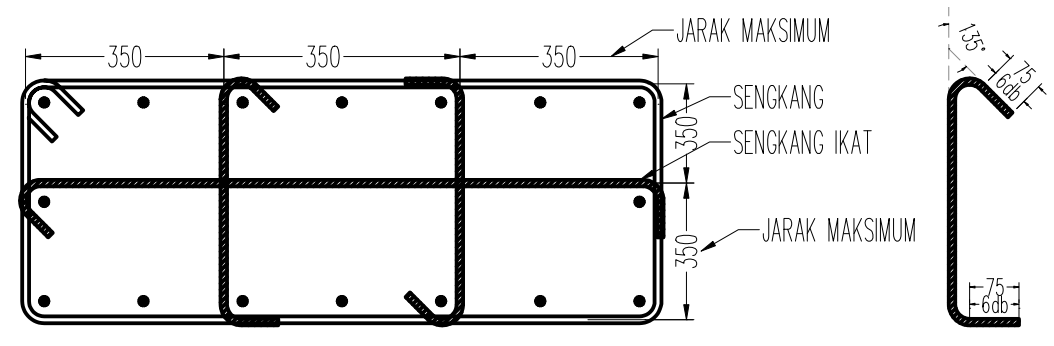

Gambar 10. Sengkang/Sengkang Ikat SRPMK.

Untuk elemen lentur balok diatas tanah, SNI-03-2847-2002 menerapkan beberapa ketentuan penting detail tulangan SRPMK sebagai berikut :

- Sengkang harus dipasang dengan spasi tidak lebih dari $1 / 2 \mathrm{~b}$ dan tidak boleh lebih besar dari $300 \mathrm{~mm}$.

\section{STUDI KASUS}

\subsection{Umum}

Dalam kenyataannya banyak sekali kasus-kasus pendetailan tulangan yang muncul, terkadang diperlukan modifikasi supaya batang-batang tulangan bisa dipasang dengan baik, modifikasi dilakukan dengan memanfaatkan faktor-faktor modifikasi yang telah disediakan oleh SNI-03-2847-2002.

\subsection{Detail Tulangan Kepala Pondasi Tiang}

Tulangan kepala pondasi tiang bor atau tiang pancang biasanya hanya ditekuk kemudian dicor digabungkan dengan pilecap, kondisi demikian hanya bisa digunakan untuk struktur biasa dan SRPMM, tetapi untuk struktur SRPMK bagian kepala pondasi tiang tersebut harus dilingkupi dengan sengkang/spiral yang berguna untuk menjaga inti beton terutama untuk tiang yang didesain menerima gaya tarik.

Sebagai contoh, pondasi tiang dengan tulangan longitudinal 6D22, mutu beton K400, diangkur ke dalam sebuah pilecap menggunakan penyaluran tulangan tanpa kait. Panjang penyaluran lurus kondisi tarik $l_{d}=42 d_{b}=924 \mathrm{~mm}$ (digunakan $l_{d}=1000 \mathrm{~mm}$ ). Untuk struktur SRPMK daerah kepala pondasi tiang harus dilingkupi sengkang/spiral, 
sedangkan untuk struktur SRPMM ketentuan tersebut tidak diharuskan, penggunaan sengkang/spiral pada kepala tiang tersebut sangat dianjurkan untuk pondasi tiang yang menerima gaya tarik.

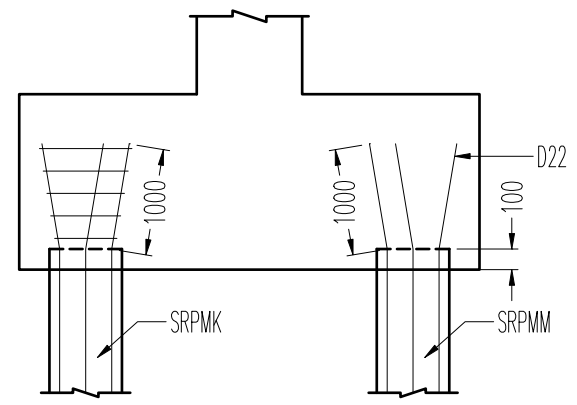

\section{Gambar 11. Detail Tulangan Kepala Pondasi Tiang SRPMK \& SRPMM.}

\subsection{Detail Tulangan Kolom Ke Pondasi}

Untuk sambungan kolom ke pondasi sangat dianjurkan untuk menggunakan panjang penyaluran tulangan berkait $90^{\circ}$ dimana kaitnya ditekuk ke arah dalam dengan maksud untuk menjaga inti beton di dalam keliling tulangan longitudinal kolom. Untuk menahan beban gempa yang bolak-balik maka menjaga inti beton sangatlah penting, karena jika inti beton menjadi rusak maka kekuatannya juga akan berkurang. Detail menurut SRPMK mengharuskan agar sengkang kolom bagian bawah diteruskan sampai ke dalam pondasi, hal ini karena SRPMK mempunyai tingkat daktilitas yang lebih tinggi daripada SRPMM sehingga dimaksudkan agar kolom mampu mengembangkan daktilitas yang dimilikinya dengan maksimal, untuk struktur SRPMM SNI-03-2847-2002 tidak mencantumkan ketentuan penerusan sengkang kolom bawah ke dalam pondasi.

Sebagai contoh, kolom kotak berdimensi 500x800, mutu beton K-400, tulangan longitudinal 12D25 diangkur ke dalam sebuah pilecap menggunakan tulangan berkait $90^{\circ}$. Panjang penyaluran tulangan tanpa kait kondisi tekan sebesar $l_{d}=28 d_{b}=700 \mathrm{~mm}$. Panjang penyaluran tulangan dengan kait $90^{\circ}$ kondisi tarik $\mathrm{l}_{\mathrm{dh}}=17 \mathrm{~d}_{\mathrm{b}}=425 \mathrm{~mm}$ (digunakan $\mathrm{l}_{\mathrm{dh}}=700$ $\mathrm{mm}$ ), ujung kait $90^{\circ}$ ditekuk $12 \mathrm{~d}_{\mathrm{b}}=300 \mathrm{~mm}$. Untuk struktur SRPMK jarak sengkang daerah $\mathrm{L}_{\mathrm{o}}$ yang akan diteruskan ke dalam pilecap diambil nilai terkecil dari $6 \mathrm{~d}_{\mathrm{b}}=150 \mathrm{~mm}$, $1 / 4 \mathrm{~b}=100 \mathrm{~mm}, \mathrm{~s}_{\mathrm{x}}=100 \mathrm{~mm}$, digunakan jarak sengkang s=100 mm. Untuk struktur SRPMM tidak disebutkan ketentuan untuk meneruskan sengkang kolom bawah ke dalam pilecap, tetapi jika secara pertimbangan perencana struktur diperlukan disarankan tetap diadakan sengkang ke dalam pondasi. 

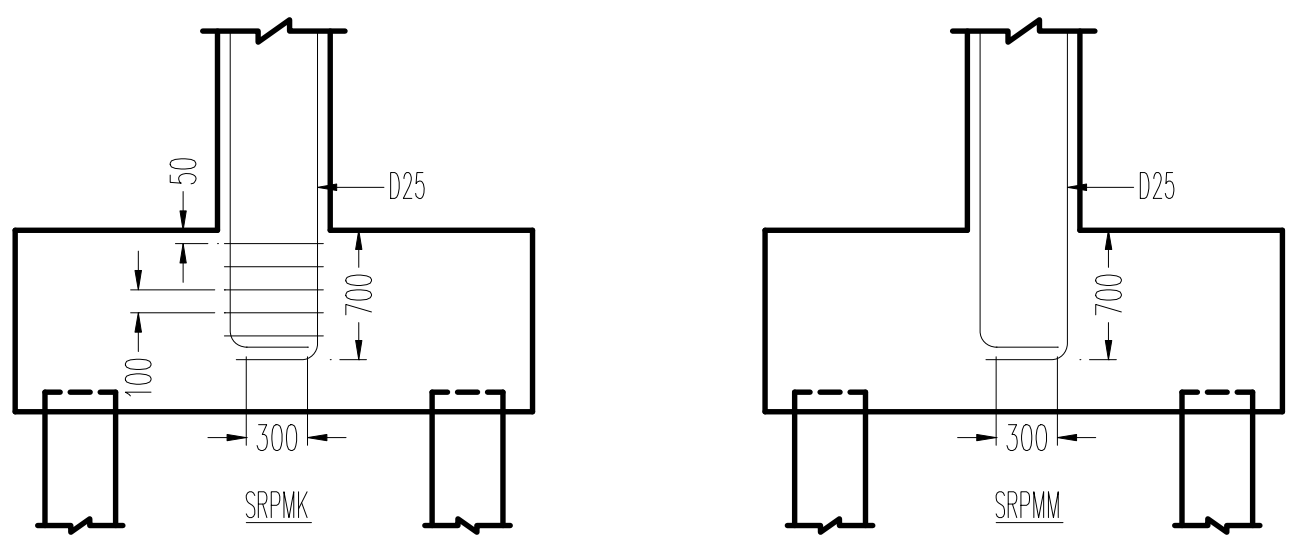

Gambar 12. Detail Tulangan Kolom ke Pondasi SRPMK \& SRPMM.

\subsection{Detail Tulangan Balok Diatas Tanah Ke Pondasi}

Tulangan balok diatas tanah atau sering disebut tie beam biasanya diangkur ke dalam pilecap walaupun ada juga yang dapat diangkur ke dalam kolom. Untuk kasus dimana tulangannya diangkur ke dalam pilecap sering dijumpai muncul masalah karena perbedaan kebutuhan tebal selimut beton antara kedua komponen struktur tersebut. Pilecap memerlukan tebal selimut beton minimum $75 \mathrm{~mm}$, jika selimut beton tie beam sebesar $50 \mathrm{~mm}$ maka tulangan negatifnya akan berada di daerah selimut beton pilecap, sisa bagian atas dari selimut beton pilecap hanya menjadi 30-40 mm, menjadi sangat tipis dan sangat beresiko pecah saat tie beam melentur. Salah satu tekniknya adalah dengan memasang sengkang sepanjang panjang penyaluran tulangan tie beam, atau dengan mempertebal selimut beton tie beam menjadi sekitar $100 \mathrm{~mm}$ tetapi akan mengakibatkan selimut beton tie beam menjadi sangat tebal sehingga desain tulangan lenturnya menjadi tidak efektif karena tulangan negatifnya terletak sangat jauh dari serat atasnya, atau bisa juga selimut beton pilecap bagian atas dipertipis menjadi sekitar 50 mm kemudian dikombinasikan dengan memodifikasi selimut beton tie beam.

Sebagai contoh, tie beam berdimensi $400 \times 700$, mutu beton K-400, tulangan longitudinal 6D25 diangkur ke dalam sebuah pilecap menggunakan tulangan berkait $90^{\circ}$. Panjang penyaluran tulangan dengan kait $90^{\circ}$ kondisi tarik $\mathrm{l}_{\mathrm{dh}}=17 \mathrm{~d}_{\mathrm{b}}=425 \mathrm{~mm}$ (digunakan $\mathrm{l}_{\mathrm{dh}}=500 \mathrm{~mm}$ ), ujung kait $90^{\circ}$ ditekuk $12 \mathrm{~d}_{\mathrm{b}}=300 \mathrm{~mm}$. Untuk struktur SRPMK jarak sengkang daerah tumpuan yang akan diteruskan ke dalam pilecap diambil $1 / 2 \mathrm{~b}=200 \mathrm{~mm}$, digunakan jarak sengkang $\mathrm{s}=150 \mathrm{~mm}$. Untuk struktur SRPMM tidak disebutkan ketentuan untuk meneruskan sengkang tumpuan tie beam ke dalam pilecap, tetapi jika secara pertimbangan perencana struktur diperlukan disarankan tetap diadakan sengkang ke dalam pilecap. 


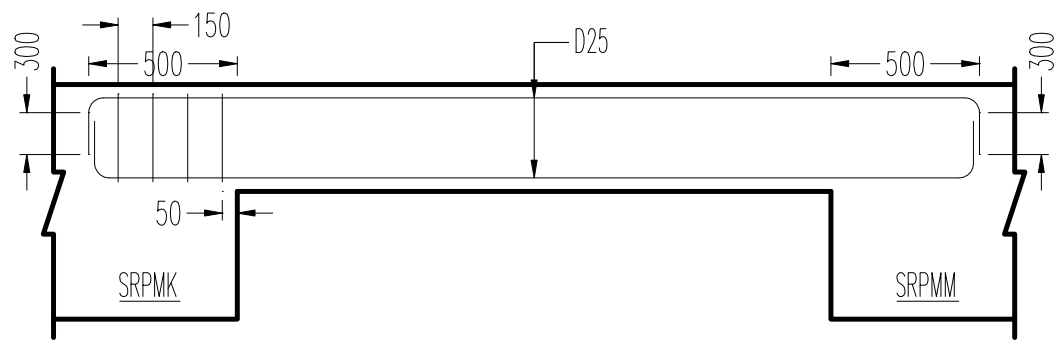

Gambar 13. Detail Tulangan Tie Beam ke Pondasi SRPMK \& SRPMM.

\subsection{Detail Tulangan Balok Ke Kolom}

Sambungan ujung balok ke kolom menggunakan panjang penyaluran tulangan dalam kondisi tarik baik untuk tulangan positif (bagian atas) maupun untuk tulangan negatif (bagian bawah). Sesuai dengan SNI-03-2847-2002, panjang penyaluran yang digunakan dapat berupa tulangan lurus, tulangan berkait $90^{\circ}$ dan tulangan berkait $180^{\circ}$, tetapi detail yang paling baik adalah detail tulangan berkait $90^{\circ}$, dimana kaitnya ditekuk ke arah bawah untuk tulangan negatif dan ditekuk ke arah atas untuk tulangan positif, hal tersebut dilakukan dengan maksud untuk menjaga inti beton di dalam keliling tulangan longitudinal balok. Untuk menahan beban gempa yang bolak-balik maka menjaga inti beton sangatlah penting, karena jika inti beton menjadi rusak maka kekuatannya juga akan berkurang. Jika mengikuti SNI-03-2847-2002 tidak disebutkan bahwa sengkang balok wajib diteruskan ke dalam joint balok-kolom, tetapi jika panjang penyaluran tulangannya kurang maka sengkang balok tumpuan harus diteruskan ke dalam joint balok-kolom, walaupun hal tersebut akan mengakibatkan detail di bagian tersebut menjadi rumit terutama untuk kolom yang penampangnya tipis.

Sebagai contoh, balok berdimensi 350x700, mutu beton K-400, tulangan longitudinal 6D22 diangkur ke dalam sebuah kolom berdimensi 500x500 menggunakan tulangan berkait $90^{\circ}$. Panjang penyaluran tulangan dengan kait $90^{\circ}$ kondisi tarik $\mathrm{l}_{\mathrm{dh}}=17 \mathrm{~d}_{\mathrm{b}}=374 \mathrm{~mm}$ (digunakan $\mathrm{l}_{\mathrm{dh}}=400 \mathrm{~mm}$ ), ujung kait $90^{\circ}$ ditekuk $12 \mathrm{~d}_{\mathrm{b}}=264 \mathrm{~mm}$ (digunakan $300 \mathrm{~mm}$ ). SNI-03-2847-2002 tidak mengharuskan untuk meneruskan sengkang balok ke dalam joint balok-kolom baik untuk struktur SRPMK maupun SRPMM, tetapi jika secara pertimbangan perencana struktur diperlukan disarankan tetap diadakan sengkang di dalam joint balok-kolom. 


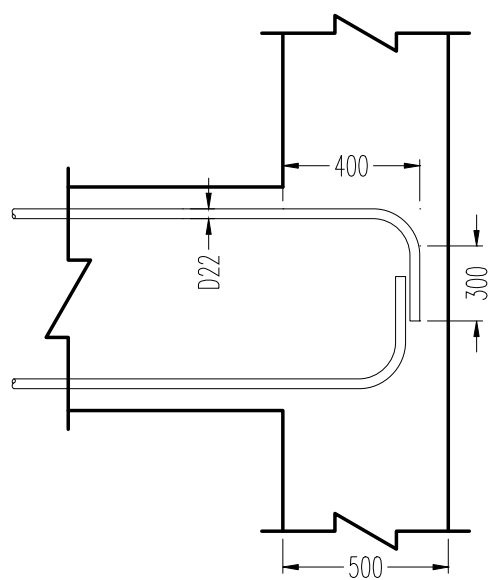

Gambar 14. Detail Tulangan Balok ke Kolom SRPMK \& SRPMM.

\subsection{Detail Tulangan Balok Ke Dinding Beton}

Dinding beton yang digunakan sebagai komponen struktur biasanya mempunyai penampang yang tipis, tebalnya bisa bervariasi dari $150 \mathrm{~mm}, 200 \mathrm{~mm}, 250 \mathrm{~mm}$ atau 300 mm. Lebar penampang yang tipis tersebut dapat mengakibatkan kesulitan dalam mengatur pengangkuran tulangan balok ke dinding beton. Beberapa tekniknya adalah dengan membesarkan jumlah tulangan balok hasil perhitungan struktur, sebagai contoh jika dari hasil perhitungan dibutuhkan jumlah tulangan sebesar 3D22 maka tulangan terpasang sengaja dibesarkan menjadi 6D22 sehingga panjang penyaluran tulangan berkait $90^{\circ}$ dapat dikurangi sebesar 3/6 $=0.5 \mathrm{kali}$, dengan memperbesar selimut beton balok menjadi $>50 \mathrm{~mm}$, panjang penyaluran tulangan berkait $90^{\circ}$ dapat dikalikan dengan faktor 0.70, dengan memasang sengkang di joint balok-kolom, panjang penyaluran tulangan berkait $90^{\circ}$ dapat dikalikan dengan faktor 0.80 .

Sebagai contoh, balok berdimensi $350 \times 700$, mutu beton K-400, tulangan longitudinal hasil perhitungan dibutuhkan 3D22, tulangan longitudinal terpasang 6D22 diangkur ke dalam sebuah dinding beton dengan tebal $250 \mathrm{~mm}$ menggunakan tulangan berkait $90^{\circ}$. Panjang penyaluran tulangan dengan kait $90^{\circ}$ kondisi tarik $l_{d h}=17 d_{b}=374 \mathrm{~mm}$ (digunakan $\mathrm{l}_{\mathrm{dh}}=400 \mathrm{~mm}$ ), ujung kait $90^{\circ}$ ditekuk $12 \mathrm{~d}_{\mathrm{b}}=264 \mathrm{~mm}$ (digunakan $300 \mathrm{~mm}$ ). Karena tebal beton yang tersedia hanya $250 \mathrm{~mm}$ dikurangi dengan selimut beton $25 \mathrm{~mm}$ menjadi 225 mm maka diperlukan modifikasi, jumlah tulangan terpasang dibuat 2x lebih besar dari jumlah tulangan kebutuhan analisis maka panjang $l_{\mathrm{dh}}$ dapat dikalikan $3 / 6=0.50$, sehingga $l_{\mathrm{dh}}$ menjadi $0.50 \mathrm{x} 400=200 \mathrm{~mm}$. Disarankan daerah joint balok-kolom dilingkupi dengan sengkang tertutup mengingat betonnya yang sangat tipis, spasi sengkang tidak boleh lebih dari $3 \mathrm{~d}_{\mathrm{b}}=66 \mathrm{~mm}$ (digunakan s=60 mm). 

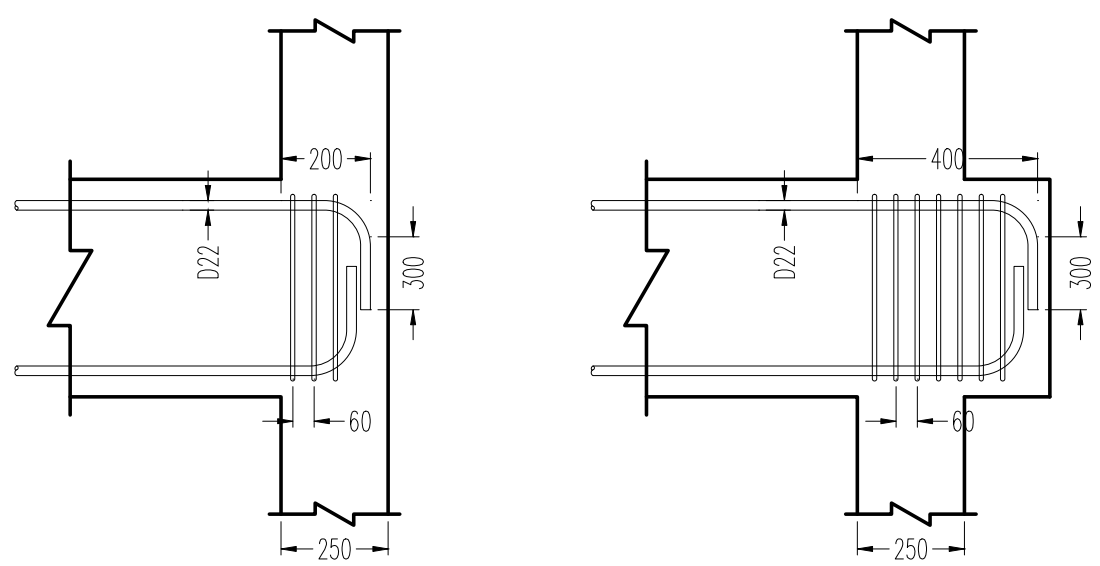

Gambar 15. Detail Tulangan Balok ke Dinding Beton SRPMK \& SRPMM.

Alternatif solusi dapat dilakukan dengan menambahkan tonjolan ke arah luar dinding beton supaya panjang penyaluran $400 \mathrm{~mm}$ tercapai, tetapi harus diperhatikan kebutuhan ruang di daerah tersebut misalnya untuk lubang lift apakah terkena dampaknya atau tidak.

\subsection{Detail Tulangan 1 Bentang Balok}

Sebagai contoh, balok berdimensi $350 \times 700$, mutu beton K-400, tulangan longitudinal D22 diangkur ke dalam sebuah kolom berdimensi 500x500 menggunakan tulangan berkait $90^{\circ}$. Panjang penyaluran tulangan dengan kait $90^{\circ}$ kondisi tarik $l_{\mathrm{dh}}=17 \mathrm{~d}_{\mathrm{b}}=374 \mathrm{~mm}$ (digunakan $\mathrm{l}_{\mathrm{dh}}=400 \mathrm{~mm}$ ), ujung kait $90^{\circ}$ ditekuk $12 \mathrm{~d}_{\mathrm{b}}=264 \mathrm{~mm}$ (digunakan $300 \mathrm{~mm}$ ). Jarak sengkang sepanjang $2 \mathrm{~h}=1400 \mathrm{~mm}$ diambil nilai terkecil dari d/4=162.5 mm, 8d $\mathrm{d}_{\mathrm{b}}=176 \mathrm{~mm}, 24 \mathrm{~d}_{\mathrm{s}}=240 \mathrm{~mm}$ dan $300 \mathrm{~mm}$ (digunakan s=150 mm), jarak sengkang di lokasi lain diambil $\mathrm{d} / 2=325 \mathrm{~mm}$. Tentunya jarak sengkang harus diperiksa terhadap kebutuhan kekuatan geser dari balok tersebut.

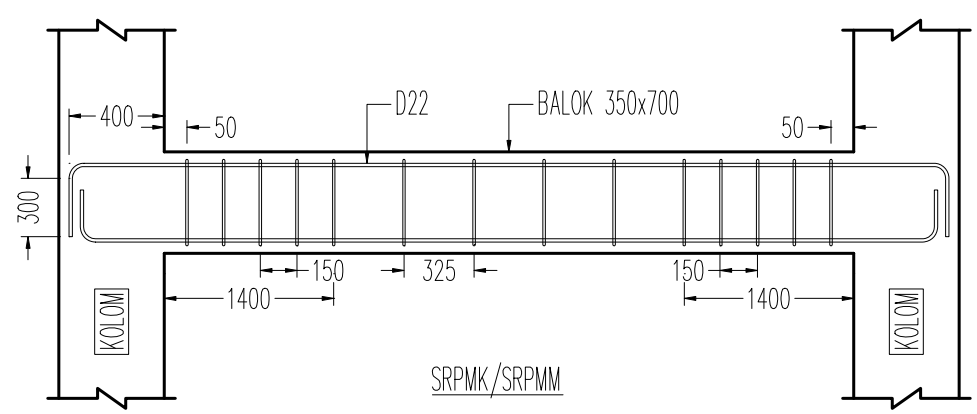

Gambar 16. Detail Tulangan 1 Bentang Balok SRPMK \& SRPMM.

Pendetailan Tulangan Struktur Beton Bertulang Tahan Gempa Sesuai Dengan SNI-03-2847-2002 (Sugito Liono) 


\subsection{Detail Tulangan 1 Bentang Kolom}

Sebagai contoh, kolom kotak tinggi 4000mm, berdimensi 500x700, mutu beton K400, tulangan longitudinal 12D25.

Untuk struktur SRPMK panjang $\mathrm{L}_{\mathrm{o}}$ diambil nilai terbesar dari $1 / 6 \mathrm{~h}_{\mathrm{n}}=670 \mathrm{~mm}$, $\mathrm{h}_{\text {kolom }}=700,500 \mathrm{~mm}$ (digunakan $700 \mathrm{~mm}$ ), jarak sengkang daerah $\mathrm{L}_{\mathrm{o}}$ diambil nilai terkecil dari $6 d_{b}=150 \mathrm{~mm}, 1 / 4 \mathrm{~b}=125 \mathrm{~mm}, \mathrm{~s}_{\mathrm{x}}=100 \mathrm{~mm}$ (digunakan jarak sengkang $\mathrm{s}=100 \mathrm{~mm}$ ). Jarak sengkang di lokasi selain $L_{o}$ diambil nilai terkecil dari $6 d_{b}=150 \mathrm{~mm}$ dan $150 \mathrm{~mm}$ (digunakan $150 \mathrm{~mm}$ ), perlu diperiksa nilai gaya aksial apakah lebih atau kurang dari $0.1 \mathrm{f}^{\prime} \mathrm{A}_{\mathrm{g}}$, jika lebih maka sengkang daerah $\mathrm{L}_{\mathrm{o}}$ dipasang di seluruh tinggi kolom. Tentunya jarak sengkang harus diperiksa terhadap kebutuhan kekuatan geser dari kolom tersebut.

Untuk struktur SRPMM panjang $\mathrm{L}_{\mathrm{o}}$ diambil nilai terbesar dari 1/6 $\mathrm{h}_{\mathrm{n}}=670 \mathrm{~mm}$, $\mathrm{h}_{\text {kolom }}=700,500 \mathrm{~mm}$ (digunakan $700 \mathrm{~mm}$ ), jarak sengkang daerah $\mathrm{L}_{\mathrm{o}}$ diambil nilai terkecil dari $8 \mathrm{~d}_{\mathrm{b}}=200 \mathrm{~mm}, 1 / 2 \mathrm{~b}=250 \mathrm{~mm}, 24 \mathrm{~d}_{\mathrm{s}}=240 \mathrm{~mm}$ dan $300 \mathrm{~mm}$, (digunakan jarak sengkang $\mathrm{s}=200 \mathrm{~mm}$ ). Jarak sengkang di lokasi selain $\mathrm{L}_{\mathrm{o}}$ diambil $2 \mathrm{~s}_{0}=400 \mathrm{~mm}$. Tentunya jarak sengkang harus diperiksa terhadap kebutuhan kekuatan geser dari kolom tersebut.
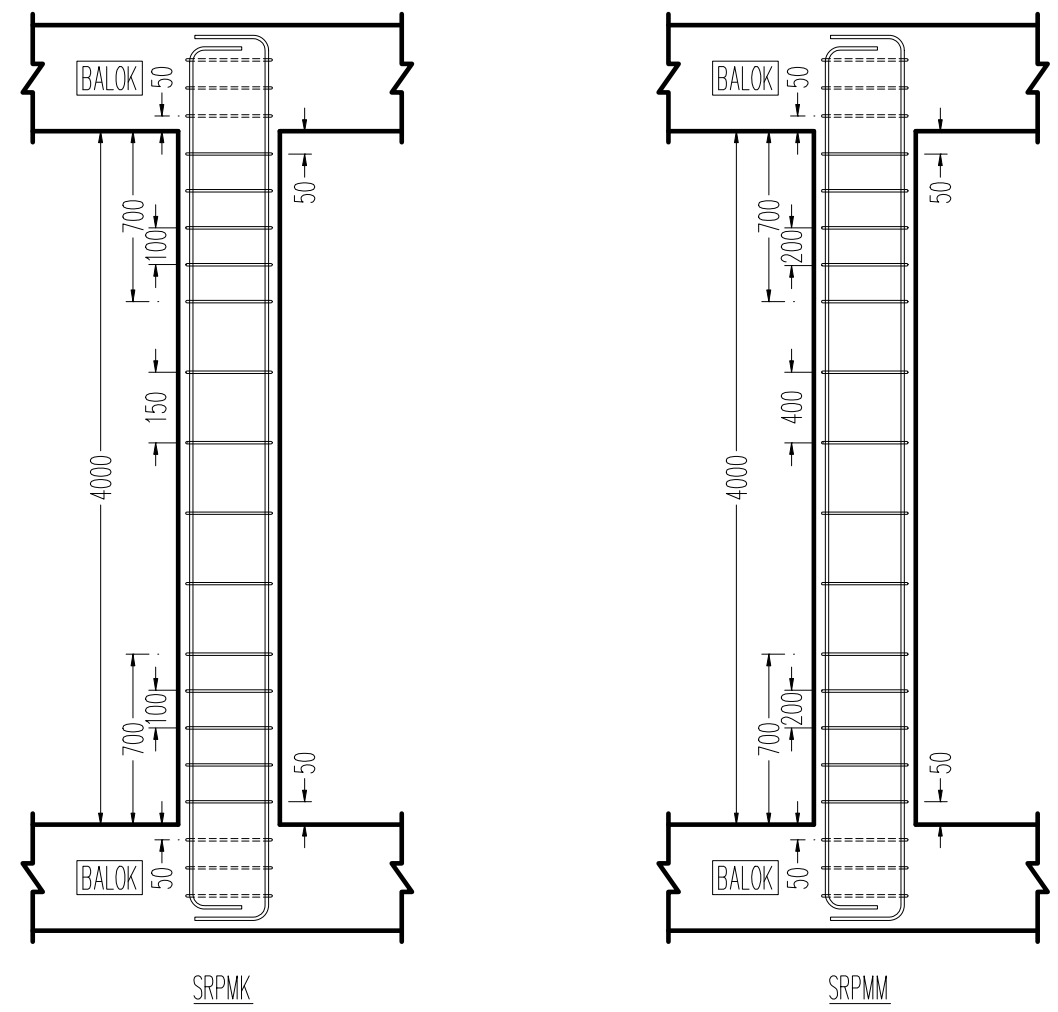

Gambar 17. Detail Tulangan 1 Bentang Kolom SRPMK \& SRPMM.

\subsection{Detail Tulangan Kolom Diatas Balok}

Dalam desain struktur terkadang dalam kasus tertentu terpaksa digunakan komponen kolom yang menumpu di atas balok, hal tersebut mungkin terjadi karena lokasi 
kolom yang memang tidak dapat diteruskan sampai dengan pondasi karena alasan arsitektur. Detail tulangan semacam ini perlu mendapat perhatian yang baik, karena kolom menumpu di sebuah komponen struktur yang melentur yaitu balok, tumpuan kolom tersebut tidak diam tetapi bisa bergerak melentur.

Sebagai contoh, kolom kotak berdimensi 500x800, mutu beton K-400, tulangan longitudinal 12D25 diangkur ke dalam sebuah balok menggunakan tulangan berkait $90^{\circ}$. Panjang penyaluran tulangan tanpa kait kondisi tekan sebesar $l_{d}=28 d_{b}=700 \mathrm{~mm}$. Panjang penyaluran tulangan dengan kait $90^{\circ}$ kondisi tarik $\mathrm{l}_{\mathrm{dh}}=17 \mathrm{~d}_{\mathrm{b}}=425 \mathrm{~mm}$ (digunakan $\mathrm{l}_{\mathrm{dh}}=700$ $\mathrm{mm}$ ), ujung kait $90^{\circ}$ ditekuk $12 \mathrm{~d}_{\mathrm{b}}=300 \mathrm{~mm}$. Walaupun dalam SNI-03-2847-2002 tidak disebutkan ketentuan detail untuk kolom diatas balok, mengingat resiko struktur yang cukup berat maka disarankan tetap diadakan pendetailan joint di area tersebut. Untuk struktur SRPMK jarak sengkang daerah $\mathrm{L}_{\mathrm{o}}$ yang akan diteruskan ke dalam balok diambil nilai terkecil dari $6 \mathrm{~d}_{\mathrm{b}}=150 \mathrm{~mm}, 1 / 4 \mathrm{~b}=125 \mathrm{~mm}, \mathrm{~s}_{\mathrm{x}}=100 \mathrm{~mm}$, digunakan jarak sengkang $\mathrm{s}=100 \mathrm{~mm}$. Untuk struktur SRPMM jarak sengkang daerah $\mathrm{L}_{\mathrm{o}}$ yang akan diteruskan ke dalam balok diambil nilai terkecil dari $8 \mathrm{~d}_{\mathrm{b}}=200 \mathrm{~mm}, 1 / 2 \mathrm{~b}=250 \mathrm{~mm}, 24 \mathrm{~d}_{\mathrm{s}}=240,300 \mathrm{~mm}$, digunakan jarak sengkang s=150 mm.

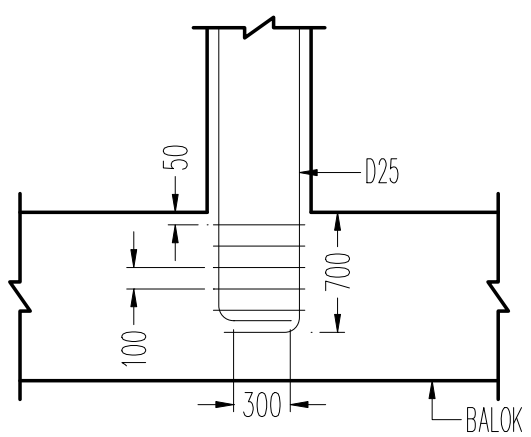

Gambar 18. Detail Tulangan Kolom Diatas Balok.

\subsection{Detail Tulangan Kolom Diatas Dinding Beton}

Sebagai contoh, kolom kotak berdimensi 250x600, mutu beton K-400, tulangan longitudinal 12D19 diangkur ke dalam sebuah dinding beton menggunakan tulangan berkait $90^{\circ}$. Panjang penyaluran tulangan tanpa kait kondisi tekan sebesar $l_{d}=28 d_{b}=532$ mm. Panjang penyaluran tulangan dengan kait $90^{\circ}$ kondisi tarik $l_{\mathrm{dh}}=17 \mathrm{~d}_{\mathrm{b}}=323 \mathrm{~mm}$ (digunakan $\mathrm{l}_{\mathrm{dh}}=600 \mathrm{~mm}$ ), ujung kait $90^{\circ}$ ditekuk $12 \mathrm{~d}_{\mathrm{b}}=228 \mathrm{~mm}$ (digunakan $250 \mathrm{~mm}$ ). Untuk struktur SRPMK jarak sengkang daerah $\mathrm{L}_{\mathrm{o}}$ yang akan diteruskan ke dalam dinding beton diambil nilai terkecil dari $6 \mathrm{~d}_{\mathrm{b}}=114 \mathrm{~mm}, 1 / 4 \mathrm{~b}=125 \mathrm{~mm}, \mathrm{~s}_{\mathrm{x}}=100 \mathrm{~mm}$, digunakan jarak 
sengkang s=100 mm. Untuk struktur SRPMM tidak disebutkan ketentuan untuk meneruskan sengkang kolom bawah ke dalam dinding beton, tetapi jika secara pertimbangan perencana struktur diperlukan disarankan tetap diadakan sengkang ke dalam dinding beton.
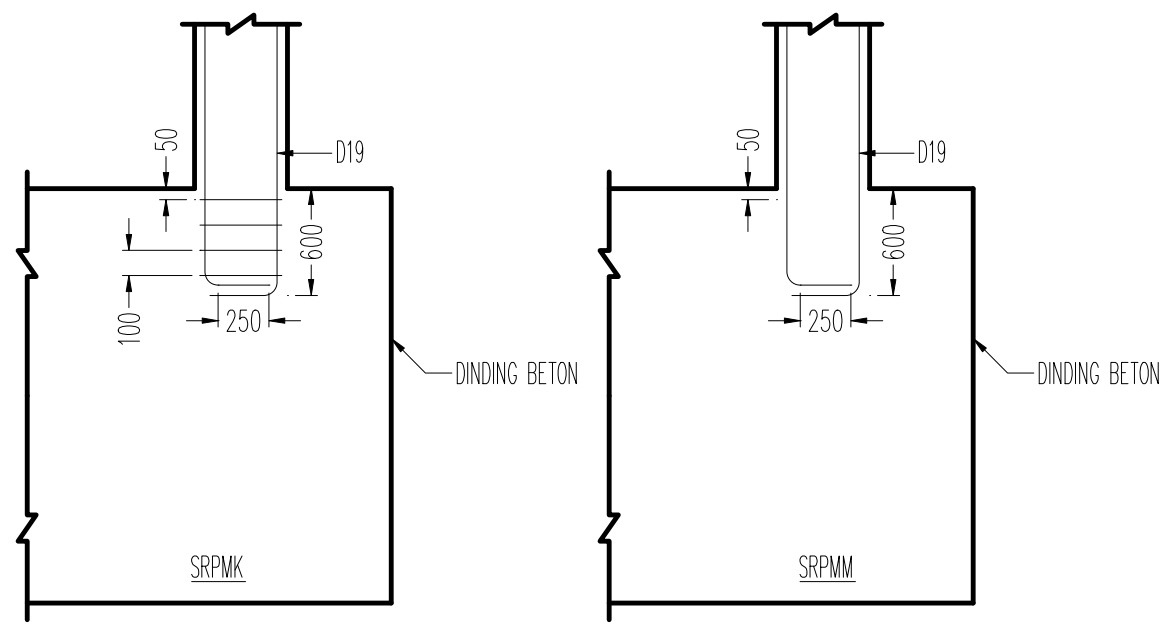

Gambar 19. Detail Tulangan Kolom Diatas Dinding Beton.

\section{PEDOMAN PRAKTIS}

Dalam prakteknya sangat dibutuhkan pedoman praktis yang mudah digunakan tetapi masih masuk dalam koridor ketentuan yang berlaku, walaupun mungkin lebih konservatif tetapi tidak sulit untuk dilaksanakan oleh pelaksana dan bisa berlaku untuk kondisi-kondisi yang umum.

Untuk sambungan pondasi tiang dengan pilecap disarankan menggunakan penyaluran tulangan tanpa kait kondisi tarik karena jika menggunakan penyaluran berkait tidak akan bisa karena tulangan longitudinal pondasi tiang sudah terpasang dan sulit untuk membengkoknya. Untuk semua nilai mutu beton, untuk tulangan $\leq$ D19 dapat digunakan nilai rata-rata $\mathrm{l}_{\mathrm{d}}=40 \mathrm{~d}_{\mathrm{b}}$, untuk tulangan $\geq \mathrm{D} 22$ dapat digunakan nilai rata-rata $l_{d}=50 d_{b}$. Untuk struktur SRPMK daerah kepala tiang wajib untuk dilingkupi dengan spiral, untuk struktur SRPMM tidak diharuskan tetapi diserahkan ke kebijakan desain sesuai pertimbangan kondisi ekstrim yang mungkin bisa terjadi. 

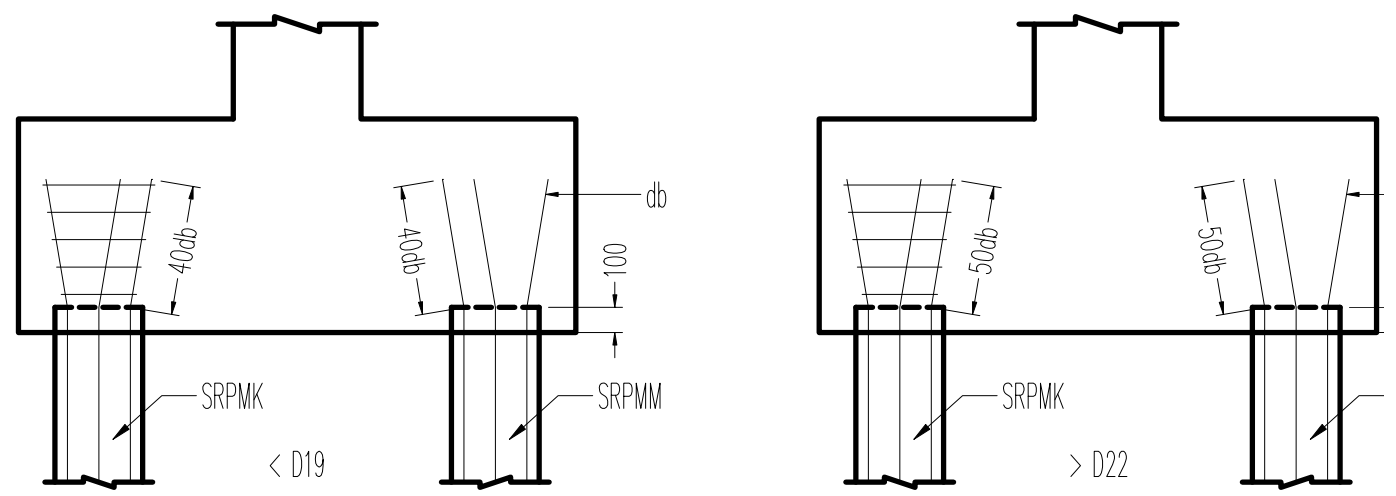

Gambar 20. Detail Tipikal Tulangan Kepala Pondasi Tiang.

Untuk sambungan kolom dengan pondasi disarankan menggunakan penyaluran tulangan dengan kait $90^{\circ}$ dimana panjang lurus yang tertanam sebesar $\mathrm{l}_{\mathrm{dh}}=30 \mathrm{~d}_{\mathrm{b}}$ (mengikuti panjang penyaluran tulangan tanpa kait kondisi tekan) dan ujungnya ditekuk sepanjang $12 \mathrm{~d}_{\mathrm{b}}$. Untuk struktur SRPMK sengkang kolom wajib diteruskan ke dalam pondasi dengan mengikuti ketentuan dalam daerah $\mathrm{L}_{0}$, untuk struktur SRPMM tidak diharuskan tetapi diserahkan ke kebijakan desain sesuai pertimbangan kondisi ekstrim yang mungkin bisa terjadi.
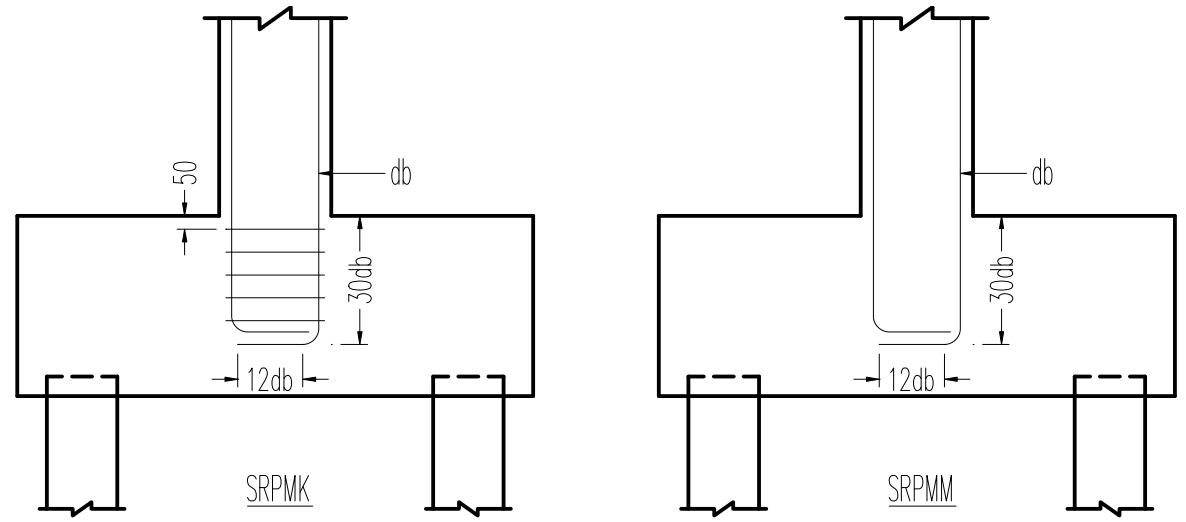

Gambar 21. Detail Tipikal Tulangan Kolom Ke Pondasi.

Untuk sambungan tie beam ke pondasi dapat menggunakan penyaluran tulangan tanpa kait kondisi tarik sebesar $l_{d}=40 d_{b}$ (tulangan $\leq$ D19) atau $l_{d}=50 d_{b}$ (tulangan $\geq D 22$ ). Penyaluran tulangan dengan kait $90^{\circ}$ dapat digunakan dengan panjang lurus yang tertanam sebesar $l_{d h}=20 d_{b}$ (mengikuti panjang penyaluran tulangan kait $90^{\circ}$ kondisi tarik) dan ujungnya ditekuk sepanjang $12 \mathrm{~d}_{\mathrm{b}}$. Seluruh panjang penyaluran harus dilingkupi sengkang tertutup dengan jarak sengkang maksimum $1 \frac{1}{2} \mathrm{~b}$. 


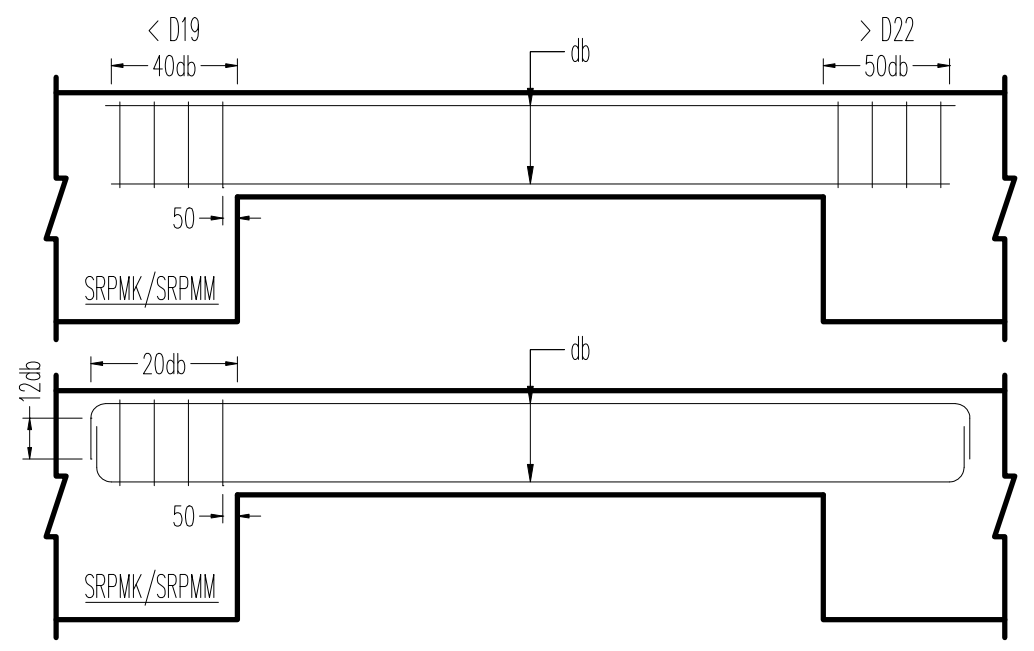

Gambar 22. Detail Tipikal Tulangan Tie Beam Ke Pondasi.

Untuk sambungan balok ke kolom disarankan menggunakan penyaluran tulangan dengan kait $90^{\circ}$ dengan panjang lurus yang tertanam sebesar $\mathrm{l}_{\mathrm{dh}}=20 \mathrm{~d}_{\mathrm{b}}$ (mengikuti panjang penyaluran tulangan kait $90^{\circ}$ kondisi tarik) dan ujungnya ditekuk sepanjang $12 \mathrm{~d}_{\mathrm{b}}$. Untuk struktur SRPMK dan SRPMM tidak diharuskan meneruskan sengkang balok ke dalam joint balok-kolom kecuali jika panjang penyaluran kurang dari yang disyaratkan atau diserahkan ke kebijakan desain sesuai kondisi ekstrim yang mungkin bisa terjadi. Untuk kondisi dimana kolomnya tipis dapat digunakan $\mathrm{l}_{\mathrm{dh}}=10 \mathrm{~d}_{\mathrm{b}}$ tetapi jumlah tulangan terpasang dibesarkan 2x dari jumlah tulangan hitungan dan disarankan sengkang balok diteruskan ke dalam joint balok-kolom dengan spasi maksimum $3 \mathrm{~d}_{\mathrm{b}}$. Alternatif lain dapat menggunakan tonjolan balok ke arah luar dinding beton sehingga panjang penyaluran tulangannya tercapai.
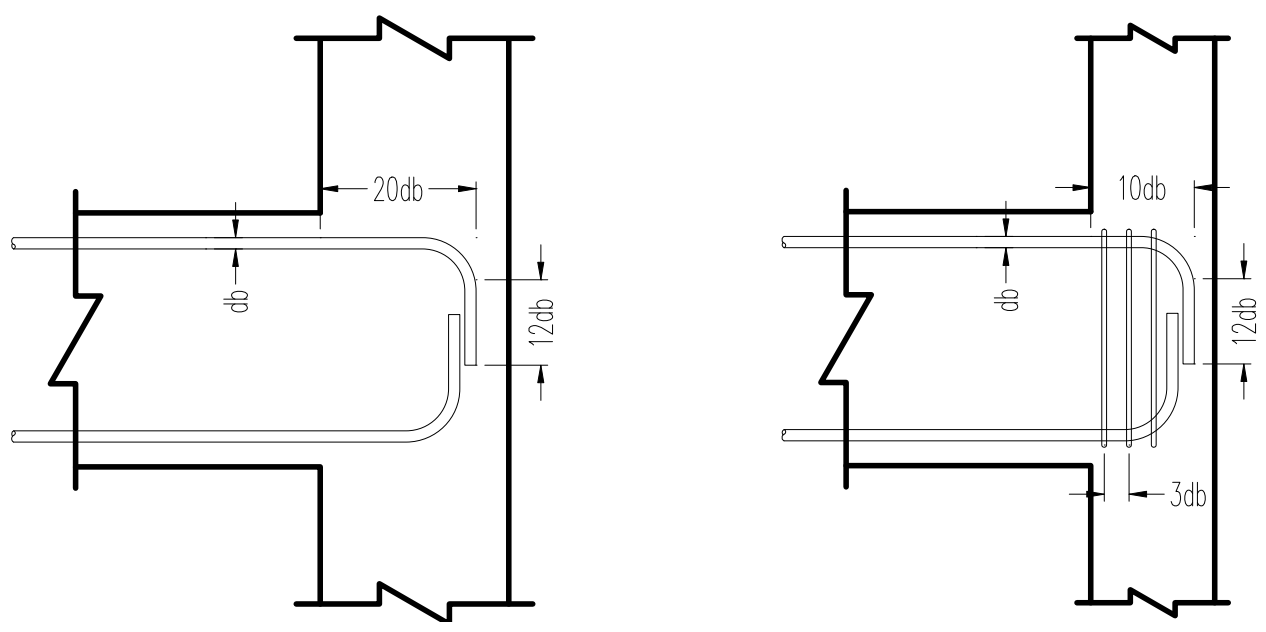

Gambar 23. Detail Tipikal Tulangan Balok Ke Kolom. 
Untuk sambungan kolom dengan balok transfer disarankan menggunakan penyaluran tulangan dengan kait $90^{\circ}$ dimana panjang lurus yang tertanam sebesar $\mathrm{l}_{\mathrm{dh}}=30 \mathrm{~d}_{\mathrm{b}}$ (mengikuti panjang penyaluran tulangan tanpa kait kondisi tekan) dan ujungnya ditekuk sepanjang $12 \mathrm{~d}_{\mathrm{b}}$. Untuk struktur SRPMK dan SRPMM sengkang kolom wajib diteruskan ke dalam balok dengan mengikuti ketentuan dalam daerah $\mathrm{L}_{\mathrm{o}}$.
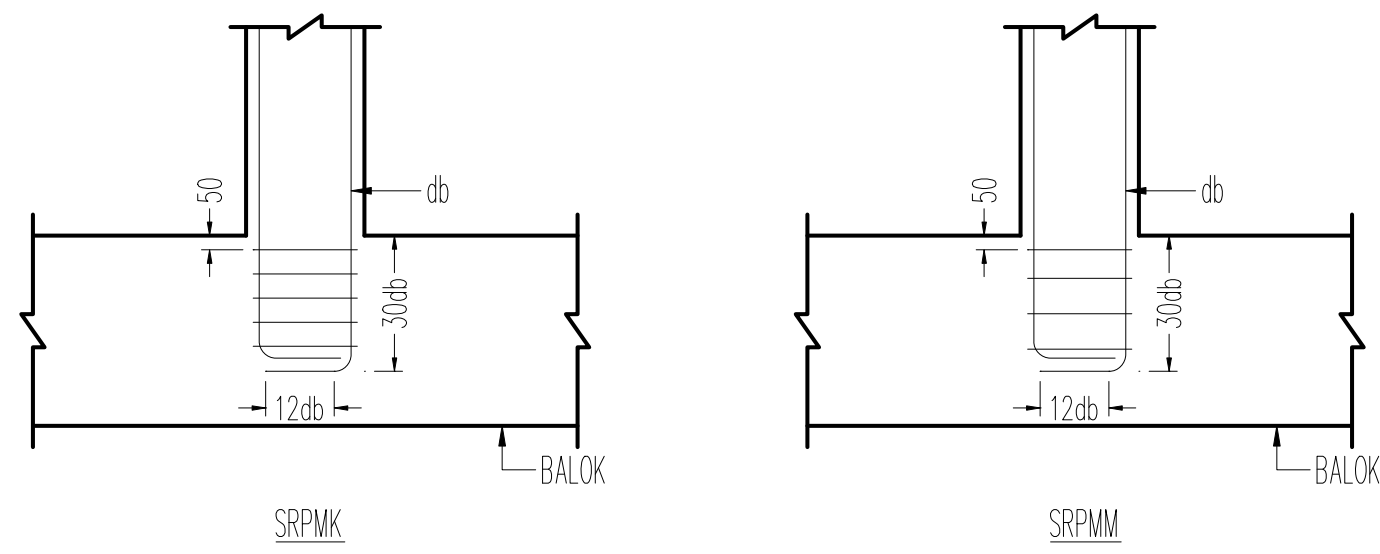

Gambar 24. Detail Tipikal Tulangan Kolom Ke Balok Transfer.

Untuk sambungan kolom dengan dinding beton disarankan menggunakan penyaluran tulangan dengan kait $90^{\circ}$ dimana panjang lurus yang tertanam sebesar $\mathrm{l}_{\mathrm{dh}}=30 \mathrm{~d}_{\mathrm{b}}$ (mengikuti panjang penyaluran tulangan tanpa kait kondisi tekan) dan ujungnya ditekuk sepanjang $12 \mathrm{~d}_{\mathrm{b}}$. Untuk struktur SRPMK sengkang kolom wajib diteruskan ke dalam dinding beton dengan mengikuti ketentuan dalam daerah $\mathrm{L}_{0}$, untuk struktur SRPMM tidak diharuskan tetapi diserahkan ke kebijakan desain sesuai pertimbangan kondisi ekstrim yang mungkin bisa terjadi terutama untuk kondisi dinding beton yang tipis. 

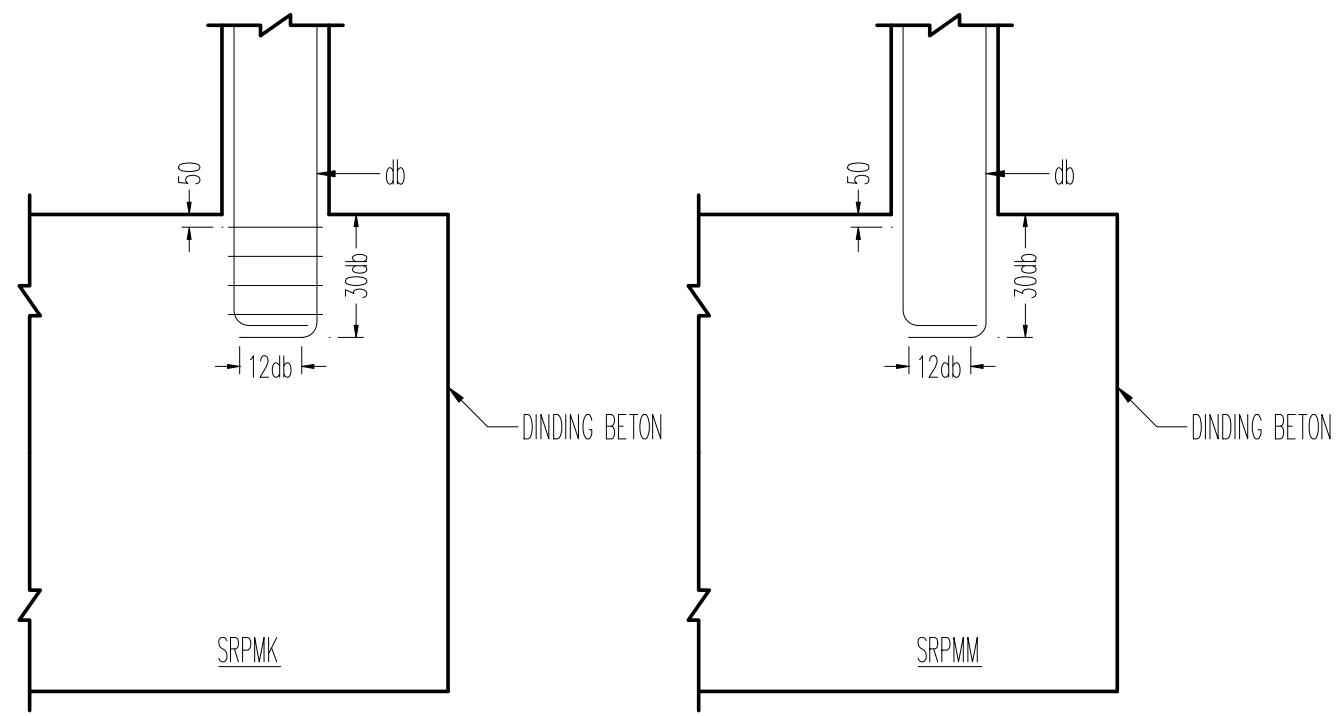

Gambar 25. Detail Tipikal Tulangan Kolom Ke Dinding Beton.

\section{KESIMPULAN}

Pendetailan tulangan merupakan hal mutlak yang harus diperhatikan dalam sebuah produk struktur karena detail-detail inilah yang akan menjaga kekuatan struktur, menjaga kekuatan sambungan-sambungan, menjaga kekuatan angkur-angkur dll terutama pada saat struktur mengalami pergerakan akibat beban gempa yang bolak-balik. Dengan pendetailan yang baik struktur juga akan mampu untuk mengembangkan daktilitasnya dengan maksimum, struktur mampu untuk berdeformasi bolak-balik diatas titik lelehnya tanpa mengalami kerusakan yang berat atau jika mengalami kerusakan masih dapat diperbaiki.

SNI-03-2847-2002 telah menyediakan beberapa ketentuan penting pendetailan tulangan, walaupun demikian dalam kasus-kasus nyata mungkin dibutuhkan modifikasimodifikasi tertentu karena belum tentu standar pendetailannya bisa terpenuhi dengan sempurna. Modifikasi tersebut tentunya membutuhkan kreatifitas, pengalaman, logika bagaimana cara dan arah gaya-gaya mengalir sehingga diharapkan modifikasi yang dilakukan tidak mengurangi kekuatan strukturnya.

Mengikuti peraturan-peraturan dunia, beberapa ketentuan detail tulangan selalu dirubah untuk ditingkatkan kinerjanya, hal tersebut dilakukan dengan mengacu ke bentuk kerusakan terbaru yang mungkin baru ditemukan setelah terjadinya sebuah gempa atau mengikuti hasil sebuah penelitian terbaru yang baru dipublikasikan secara internasional, detail tulangan yang saat ini berlaku sangat mungkin harus dimodifikasi pada saat-saat mendatang dengan tujuan untuk meningkatkan kinerjanya. 


\section{REFERENSI}

1. ACI Committee 318 (2008), Building Code Requirements for Structural Concrete and Commentary, USA.

2. Badan Standarisasi Nasional (2002), Tata Cara Perancangan Struktur Beton Untuk Bangunan Gedung (SNI-03-2847-2002), BSN, Jakarta, Indonesia.

3. Badan Standarisasi Nasional (2002), Standar Perencanaan Ketahanan Gempa Untuk Struktur Bangunan Gedung (SNI-03-1726-2002), BSN, Jakarta, Indonesia.

4. Leet, Kenneth \& Bernal, Dionisio, (1997), Reinforced Concrete Design, 3rd Ed., McGraw - Hill International, Singapore.

5. MacGregor, James G., (2008), Reinforced Concrete - Mechanics And Design, 4th Ed., Prentice - Hall Inc., New Jersey, USA.

6. Nawy, Edward G., (2008), Reinforced Concrete - A Fundamental Approach, 6th Ed., Prentice - Hall, Inc., New Jersey, USA.

7. NEHRP Seismic Design Technical Brief No. 1 (2008), Seismic Design of Reinforced Concrete Special Moment Frames : A Guide for Practicing Engineers, USA. 